\title{
Modelling thermal and humidity transfers within green roof systems: effect of rubber crumbs and volcanic gravel
}

\author{
Mostafa Kazemi $^{1} *$, Luc Courard ${ }^{2}$ \\ Corresponding author*
}

1- Ph.D. Candidate, GeMMe Building Materials, Urban and Environmental Engineering (UEE), University of Liege, Liège, Belgium, E-mail: mostafa.kazemi@uliege.be

2- Full Professor, GeMMe Building Materials, Urban and Environmental Engineering (UEE), University of Liege, Liège, Belgium, Email: luc.courard@uliege.be

\begin{abstract}
The use of recycled materials and porous aggregates such as rubber crumbs and volcanic gravel (pozzolana) for the drainage layer can lead to improving thermal behaviour of the green roofs. On the other hand, the thermal performances of green roofs can be affected by the thickness of substrate and drainage layer. Therefore, the main objective of this study was to adapt modelling characteristics for different thicknesses of substrate and drainage layers used under constant and variable temperatures and solar radiation: specific rubber crumbs and volcanic gravel behaviour has been modelled. The simultaneous heat and moisture transfers within the green roof were estimated as well. According to the results, the $9 \mathrm{~cm}$ substrate was recommended to be used for the green roofs, once the thickness of drainage layer was $4 \mathrm{~cm}$. Moreover, the optimum thickness of pozzolana and rubber crumbs as drainage layer was $6 \mathrm{~cm}$ and $7 \mathrm{~cm}$, respectively, once the thickness of the substrate was kept constant $(5 \mathrm{~cm})$. By increasing the thickness of substrate and drainage layers, the fluctuation of internal ceiling temperature in the green roof models with the presence of humidity decreased, but not as much as that in the green roof models without the presence of humidity.
\end{abstract}

Keywords: modelling; thermal behaviour; relative humidity; drainage layer; substrate.

\section{Introduction}

The high energy consumption of houses has been known as a serious concern in the construction sector, and it is estimated that about $40 \%$ of total primary energy consumption is used by the houses and building sector in the European Union (EU) (Coma et al. 2014; Soleimani et al. 2020; Karatzas and Katsifarakis 2018; Ramin et al. 2019). One of the innovative solutions to improve the energy savings in the building sector is to substitute common flat roofs with green roofs, which can provide a good thermal performance at the top of houses (Coma et al. 2016; Theodosiou 2011; Ebadati and Ehyaei 2018; Ferrante et al. 2015; Yu and Hien 2009). According to the thickness of green roof, it can be classified into three categories: intensive, semi-intensive, and extensive. The thickness and weight of extensive green roof are in the range of $60-200 \mathrm{~mm}$ and $70-170 \mathrm{~kg} / \mathrm{m}^{2}$, respectively, and it has drawn the attention of researchers in the building sector due to its shallower depth and lighter weight than other categories of green roof (Oberndorfer et al. 2007; Raji et al. 2015).

The extensive green roof has different layers including vegetation, substrate, filter, drainage and insulation layers (Tabares-Velasco et al. 2012). In some cases, the polyethylene modular panel (egg-carton-shaped panel) has been used for the drainage layer of green roof (Jim 2014; Dvoraka and Volder 2013; Vesuviano and Stovin 2013; Jim and Tsang 2011; Papafotiou et al. 2013; Mickovski et al. 2013; Chenani et al. 2015). Other researchers have proposed to use natural aggregates for this layer (Wanielista et al. 2008). Wanielista et al. (2008) performed a 
comparison between the use of polyethylene modular panel and natural gravel aggregate for the drainage layer. They revealed that the quality of water leaked from the natural gravel aggregate was nearly the same as that leaked from the polyethylene modular panel. In addition, the evapotranspiration process in the green roof with the natural gravel aggregate as the drainage layer increased by increasing the atmospheric temperature. A study by Parizotto and Lamberts (2011) assessed the thermal performance of green roof with gravel and pebble as drainage layer. As per the results, the thermal mass was added to the green roof due to the diffusive properties of substrate and drainage layer, leading to the absorption of large amounts of heat and delaying the heat transfer processes and subsequently declining the diurnal temperature variation. Furthermore, during the warm period, the green roof increased the heat loss by $49 \%$ and $20 \%$ more than ceramic and metallic roofs, respectively, and decreased the heat gain to $92 \%$ and $97 \%$. Uhl and Schiedt (2008) used the broken expanded slate as drainage layer. According to the results, the dewatering of the substrate was accelerated due to high porosity of the broken expanded slate.

Although the drainage layer with natural aggregates can be considered as a permeable layer, which is very important for the leakage of water from the green roof (Uhl and Schiedt 2008; Vijayaraghavan et al. 2012; AzariJafari et al. 2015), the use of natural aggregates in the drainage layer imposes a heavy burden on the environment and construction sector owing to the consumption of natural resources and higher energy required for their transformation process (Vila et al. 2012; Berardi et al. 2014; Toghroli et al. 2020; Nematzadeh et al. 2020; Madandoust et al. 2020; Saberian et al. 2019a; Crafford et al. 2018). These issues can be somewhere solved by the substitution of natural aggregates with recycled materials and porous aggregates such as rubber crumbs, volcanic porous gravel, and the crushed brick, reducing the consumption of natural materials and providing a suitable thermal behaviour in the extensive green roof, as already confirmed by other researchers (Coma et al. 2016; Pérez et al. 2012; Berardi et al. 2014; Jafari and Toufigh 2017; Karamanis et al. 2013). In addition, the recycled and porous materials have greater porosity and more water retention capacity than the natural aggregate (Kazemi et al. 2020; Zhao et al. 2020; Kazemi et al. 2019; Karamanis et al. 2013; Courard et al. 2020), providing a suitable condition to irrigate the vegetation of green roofs, particularly during the warm periods. In this regard, to save the raw materials, the recycled crushed brick was proposed by Ngan (2004) to be utilized for the drainage layer and growing media. Another study by Berndtsson et al. (2006) on the extensive green roofs showed that the crushed brick as drainage layer slightly retained small particles, released from the soil, and somewhat prevented washing them away. Palla et al. (2009) proposed the Lapillus (a volcanic porous material) as drainage layer in the green roof, which on one hand had a high water retention capacity and on the other hand, allowed the extra water to drain from the green roof.

The concept of thermal insulation can be referred to the reduction of heat transfer between objects of differing temperature (Deshmukh et al. 2017). For the thermal insulation performance of materials, three indicators have been introduced including thermal inertia index, thermal resistance, and thermal storage coefficient, which are attributed to the temperature fluctuation (Ling et al. 2016; CABR 2014). Recently, the thermal performance of green roof with the drainage layer of perlite, expanded clay, and rubber crumbs was assessed by Cascone et al. (2018). They concluded that, the use of green roof decreased the energy consumption for the cooling of building by 31-35\% during summer period. The corresponding value for heating was $2-10 \%$ during the cold period. Meanwhile, the diurnal temperature fluctuations of building with 
the green roof decreased in comparison to that with the traditional roof, owing to higher thermal inertia generated by the drainage layer and substrate.

To simulate thermal and moisture transfer processes, the modelling tools have been widely used by researchers and a list of hygrothermal simulation software was provided by Delgado et al. (2013) to apply to building physics. Some hygrothermal simulation tools have met the criteria required for the heat and moisture transfer within green roof systems (ASHRAE Standard 160 2009; Burch and Chi 1997; Künzel 1994). Among the approved tools, the WUFI simulation software has been chosen for further use by researchers to simulate the bond between moisture and heat transfer through green roof layers owing to some reasons including higher accuracy of hygrothermal simulation results in comparison with experimental measurements under different climate conditions over a long-period monitoring (Schafaczek and Zirkelbach 2013). Considering the rainwater reception and water drainage effect through the greenery layers are other advantages of WUFI simulation software (Zirkelbach et al. 2017; Vertal' et al. 2018). In addition to the above, the moisture properties of materials including liquid water transport and vapour diffusion can be easily measured in lab-scale and then introduced into the WUFI software to predict the hygrothermal performance of green roof layers (Vertal' et al. 2018). A study by Zirkelbach (2017) on the hygrothermal performance of extensive green roof showed that the WUFI was able to well reproduce the moisture and thermal performance of green roof layers in comparison with experimental measurements, leading to a better understanding of energetic consequences for green roof systems. In addition, Zirkelbach (2017) demonstrated that the effect of natural weather conditions with precipitation in summer and winter could be considered using more detailed simulation of the moisture balance in the substrate layer. In another study by Vertal' et al. (2018), the WUFI simulation tool was used with good accuracy for the generation of strong bond between moisture and heat transfer through green roof layers. According to the results, the water content reduced the average daily heat flow across the green roof by $11 \%$, leading to decreasing its summer overheating. To assess the potential thermal performance of green roof systems, researchers (Ting 2011; Lei et al. 2019) has also used a finite element software, namely ABAQUS (Dassault Systemes 2009) to assess the thermal performance of green roof systems. This software is able to accurately predict the thermal distribution through different depths of substrate and drainage layers. The thermal parameters can be easily obtained in laboratory to introduce to ABAQUS software (Ting 2011; Lei et al. 2019). Recently, Lei et al. (2019) simulated the green roof layers to evaluate their performance for improving the indoor thermal comfort. As per the results, the green roof system effectively participated in decreasing the indoor temperature up to $4^{\circ} \mathrm{C}$ in comparison to bare roofs particularly during summer period, while its insulation performance during the cold period was negligible.

Generally, the hygrothermal simulation tools can be utilized further to shed some light on heat and moisture transfers into the green roof layers with different thicknesses and materials. Concerning this, Eksi et al. (2017) introduced key factors in the improvement of green roof performance including weather conditions, substrate moisture content, evapotranspiration phenomenon, substrate depth, and plant type. According to the results, in a warmer summer climate, the night-time radiation of heat severely transferred into the building from a deep substrate layer owing to warmer air temperatures and sun exposure, while night-time heat transfer into a deep substrate of green roof systems was not observed for a cooler summer climate. Therefore, it can be stated that there is a demand for simulating the green roof with different thicknesses of substrate layer to assess its hygrothermal performance under summer weather conditions. On the other hand, Bianchini and Hewage (2012) reported that the drainage 
and filter layers are manufactured with $40 \%$ recycled polypropylene, which has harmed the environment owing to the air pollution generated by the polymer's production process. For this reason, Vijayaraghavan (2016) recommended to substitute the polyethylene modular panel with suitable materials to improve the sustainability of green roof systems. More importantly, Vijayaraghavan (2016) pointed out that the effect of different components on the insulation and thermal properties of green roof are not well known. This in turn has raised a need to perform further studies for simulating the thermal and moisture transfer within green roof systems made with alternative materials as drainage layer, where the sensitivity of these materials are required to be assessed (Kapsalis et al. 2014; Vijayaraghavan 2016) using hygrothermal and thermal simulation tools such as WUFI and ABAQUS software.

To assess the thermal performances of green roof with a drainage layer made of rubber crumbs and volcanic gravel, a long-term experimental works was performed in Spain by Coma et al. (2014; 2016), Pérez et al. (2012; 2012), Navarro et al. (2012) and Vila et al. (2012). Regarding this, the useability of rubber crumbs instead of volcanic gravel as drainage layer was first confirmed by Vila et al. (2012). During summer 2011, Coma et al. (2014) performed some tests on identical house-like cubicles with green roofs in Puigverd de Lleida (Spain), where there was a dry, Mediterranean climate with low precipitation. The results showed that the green roof with the substrate and rubber crumbs and volcanic gravel as drainage layer provided better thermal insulation performance than that of the conventional flat roof. During summer 2012, Coma et al. (2016) assessed the insulation performance of the same green roofs in Puigverd de Lleida (Spain) once the effect of moisture was not negligible. Therefore, they assessed the integrated effect of temperature and humidity on the extensive green roof with the drainage layer of rubber crumbs and volcanic gravel. The results showed that the green roof with rubber crumbs provided more energy savings than volcanic gravel as drainage layer. Following this, Pérez et al (2012) revealed that the use of the accumulated energy consumption of house-like cubicles with rubber crumbs and volcanic gravel as drainage layer under inside temperature of $24^{\circ} \mathrm{C}$ decreased up to $3.5 \%$ and $15 \%$, respectively, in comparison with the conventional flat roof.

Generally, to get a better understanding of the temprature distribution of extensive green roofs with different types of materials, there is a necessity to assess the thermal and humidity transfers within the green roof models. Furthermore, the thermal performance of green roof models using recycled materials and porous aggregates as drainage layer has rarely been simulated. Moreover, only few studies have been conducted to model the simultaneous temperature and humidity transfers within green roof models. In addition, providing the design recommendations for the optimum thickness of green roof layers is essential to achieve a suitable thermal perfomance for the inside temperature of the houses and buildings (Coma et al. 2016; Mickovski et al. 2013). Therefore, the objective of this study was to adapt modeling characteristics for the green roof models with different thicknesses of substrate and drainage layers used under constant and variable temperatures and solar radiation: specific rubber crumbs and volcanic gravel behaviour has been simulated. To achieve this goal, the temperature fluctuations in green roof models were assessed, where the models were developed and exposed to outside weather conditions (variable temperatures and solar radiation) of Lleida for the summer period of 2011. Thereafter, a parametric study was carried out to assess the temperature transfer through substrate and drainage layers. Furthermore, the models were exposed to the weather conditions of Lleida for the summer period of 2012, when environmental conditions included solar radiation and outside temperature as well as outside relative humidity. Finally, the simultaneous effect of temperature 
and relative humidity on green roof models with different thicknesses of substrate and drainage layers was studied.

\section{Green roof modelling}

\subsection{Details of green roof models}

In this study, the pure thermal performance of green roof models was first developed using the ABAQUS software, which is suitable for the thermal simulation in the green roof (Lei et al. 2019; Ting 2011). The properties of materials given by Coma et al. (2016) were used for the thermal modelling simulation. They extracted data from Sailor and Hagos (2011) to realistically predict the thermal behaviour of green roof layers. Concerning this, the density, thermal conductivity and specific heat for the drainage layer of pozzolana were equal to $830 \mathrm{~kg} / \mathrm{m}^{3}, 0.55$ $\mathrm{W} / \mathrm{m} \mathrm{K}$, and $1000 \mathrm{~J} / \mathrm{kg} \mathrm{K}$, respectively. The corresponding values for the drainage layer of rubber crumbs were $610 \mathrm{~kg} / \mathrm{m}^{3}, 0.13 \mathrm{~W} / \mathrm{m} \mathrm{K}$, and $1000 \mathrm{~J} / \mathrm{kg} \mathrm{K}$, respectively. These values for substrate were obtained $940 \mathrm{~kg} / \mathrm{m}^{3}, 0.435 \mathrm{~W} / \mathrm{m} \mathrm{K}$, and $1420 \mathrm{~J} / \mathrm{kg} \mathrm{K}$, respectively.

Twenty green roofs were numerically modelled in which the models with the reference numbers of 1 and 11 (Table 1) were first simulated and verified with the experimental outputs, given by Coma et al. (2014; 2016) and Pérez et al. (2012). They carried out experiments on the green roof specimens with pozzolana (volcanic gravel) and rubber crumbs as drainage layer under constant inside temperature $\left(24{ }^{\circ} \mathrm{C}=297.15 \mathrm{~K}\right)$ during a 6-day period (518400 s) on July 2011 in Lleida. During this period, the weather conditions included the variable solar radiation and outside temperature as measured by Coma et al. (2014) (Fig. 1). In the aforementioned green roof models, the thicknesses of drainage layer and substrate were equal to $4 \mathrm{~cm}$ and $5 \mathrm{~cm}$, respectively. Later on, by keeping constant the thickness of substrate, the thickness of drainage layer with pozzolana and rubber crumbs numerically increased up to $5,6,7$, and $8 \mathrm{~cm}$ (the reference numbers of 2-5 and 12-15 in Table 1). Thereafter, by keeping constant the thickness of drainage layer, the thickness of substrate increased up to $6,7,8,9$, and $10 \mathrm{~cm}$ (the reference numbers of 6-10 and 16-20 in Table 1).

Table 1. Details and geometrical characteristics of green roofs.

\begin{tabular}{|c|c|c|c|c|}
\hline \multirow{2}{*}{ No. } & \multirow{2}{*}{ Specimen } & \multirow{2}{*}{ Materials for drainage layer } & \multicolumn{2}{|c|}{ Thickness $(\mathrm{cm})$} \\
\hline & & & Drainage layer & Substrate \\
\hline 1 & $\mathrm{P}^{\mathrm{a}} 4-\mathrm{S}^{\mathrm{b}} 5$ & Pozzolana & 4 & 5 \\
\hline 2 & P5-S5 & Pozzolana & 5 & 5 \\
\hline 3 & P6-S5 & Pozzolana & 6 & 5 \\
\hline 4 & P7-S5 & Pozzolana & 7 & 5 \\
\hline 5 & P8-S5 & Pozzolana & 8 & 5 \\
\hline 6 & P4-S6 & Pozzolana & 4 & 6 \\
\hline 7 & P4-S7 & Pozzolana & 4 & 7 \\
\hline 8 & P4-S8 & Pozzolana & 4 & 8 \\
\hline 9 & P4-S9 & Pozzolana & 4 & 9 \\
\hline 10 & P4-S10 & Pozzolana & 4 & 10 \\
\hline 11 & $\mathrm{RC}^{\mathrm{c}} 4-\mathrm{S} 5$ & Rubber crumbs & 4 & 5 \\
\hline 12 & RC5-S5 & Rubber crumbs & 5 & 5 \\
\hline 13 & RC6-S5 & Rubber crumbs & 6 & 5 \\
\hline 14 & RC7-S5 & Rubber crumbs & 7 & 5 \\
\hline 15 & RC8-S5 & Rubber crumbs & 8 & 5 \\
\hline 16 & RC4-S6 & Rubber crumbs & 4 & 6 \\
\hline 17 & RC4-S7 & Rubber crumbs & 4 & 7 \\
\hline 18 & RC4-S8 & Rubber crumbs & 4 & 8 \\
\hline 19 & RC4-S9 & Rubber crumbs & 4 & 9 \\
\hline 20 & RC4-S10 & Rubber crumbs & 4 & 10 \\
\hline
\end{tabular}




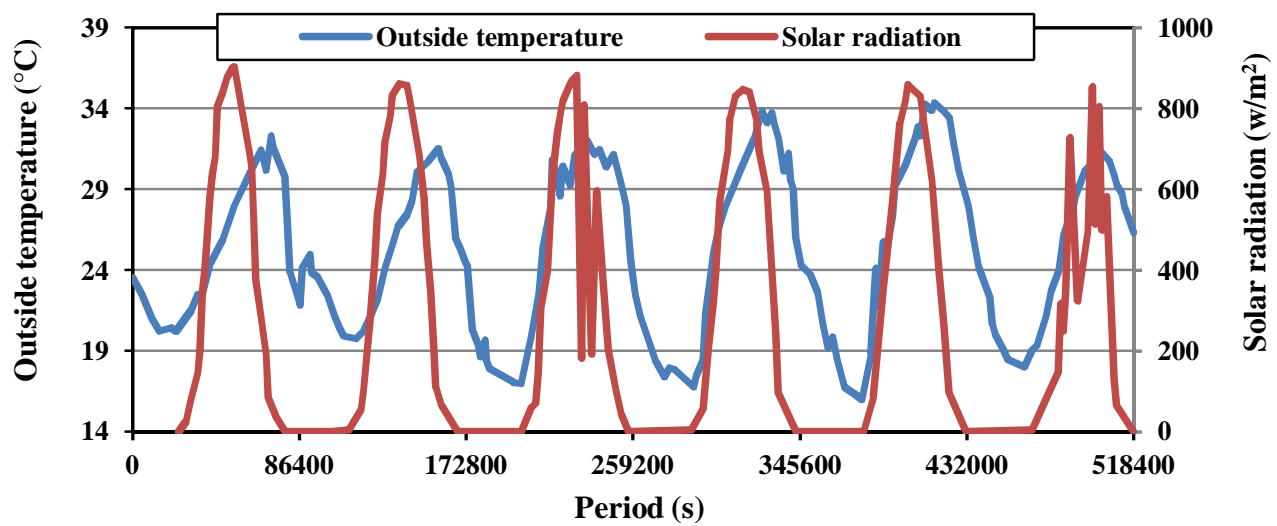

Fig. 1. Outside temperature and solar radiation at the beginning of July 2011 for a 6-day period (518400 s) in Lleida (Spain) (Coma et al. 2014).

To assess the integrated effect of temperature and humidity on different layers of the extensive green roof including substrate and drainage layers, the WUFI software was used, which is suitable to model the simultaneous heat and moisture transfer into the buildings (Budaiwi and Abdou; 2013; Antretter et al. 2011; Amiri Fard et al. 2019; Altamirano-Medina et al. 2009). To realistically simulate the thermal performance of materials in WUFI software, the data given by Coma et al. (2016) were used as already presented. In addition, the porosity and water vapour diffusion resistance of rubber crumbs, pozzolana and substrate were required for the simulation of humidity transfer into the depth of the green roof models. Concerning this, the approximate values for the porosity of rubber crumbs, pozzolana and substrate were assumed to be $50 \%, 57 \%$, and $40 \%$, respectively, similar to what were proposed by other researchers (Stovin et al. 2015; Pfretzschner and Rodriguez 1999; Tommasi et al. 2015). Moreover, the water vapour diffusion resistance factor of substrate was considered to be 5 (Schulte-Wrede et al. 2012). The drainage layer included granular materials of pozzolana and rubber crumbs and it was very permeable. Therefore, the water vapour diffusion resistance factor for this layer was assumed to be 1 as recommended by Fraunhofer IBP (2015).

For the hygrothermal simulation of green roof systems, the models with the reference numbers of 1 and 11 (Table 1) were simulated using WUFI software once again and they were verified with the experimental outputs, given by Coma et al. $(2014$; 2016) and Pérez et al. (2012) for the green roof specimens under constant inside temperature during a 6-day period (518400 s) on July 2011 in Lleida. Fig. 1 shows the weather conditions for this period which included the variable solar radiation and outside temperature as measured by Coma et al. (2014). After the verification, the outside weather conditions on July 2011 in Lleida (Fig. 1) were replaced with those on July 2012 in Lleida (Fig. 2) prepared by Coma et al. (2016) in which the verified models were exposed to the variable solar radiation and outside temperature as well as outside relative humidity. Thereafter, the integrated effect of temperature and humidity on green roofs was assessed, particularly for the summer period. Finally, another parametric study was carried out using WUFI software to evaluate the simultaneous effect of temperature and relative humidity transfer within the green roof models with different substrate and drainage layer thicknesses.

It is noteworthy that the plants covered only $20 \%$ of the surface of substrate and they were in a growth phase during summer 2011. Therefore, the vegetation coverage was scarce and the sunlight shined directly through the surface of the substrate, which provided a suitable condition 
to evaluate the effect of the solar radiation and outside temperature on the substrate and drainage layers as mentioned by Coma et al. (2014). In addition, they fabricated the experimental cubicle specimens without filter and insulation layers and revealed that the effect of rainfall on the thermal performance of cubicle specimens was negligible owing to the dry and Mediterranean climate of Lleida.

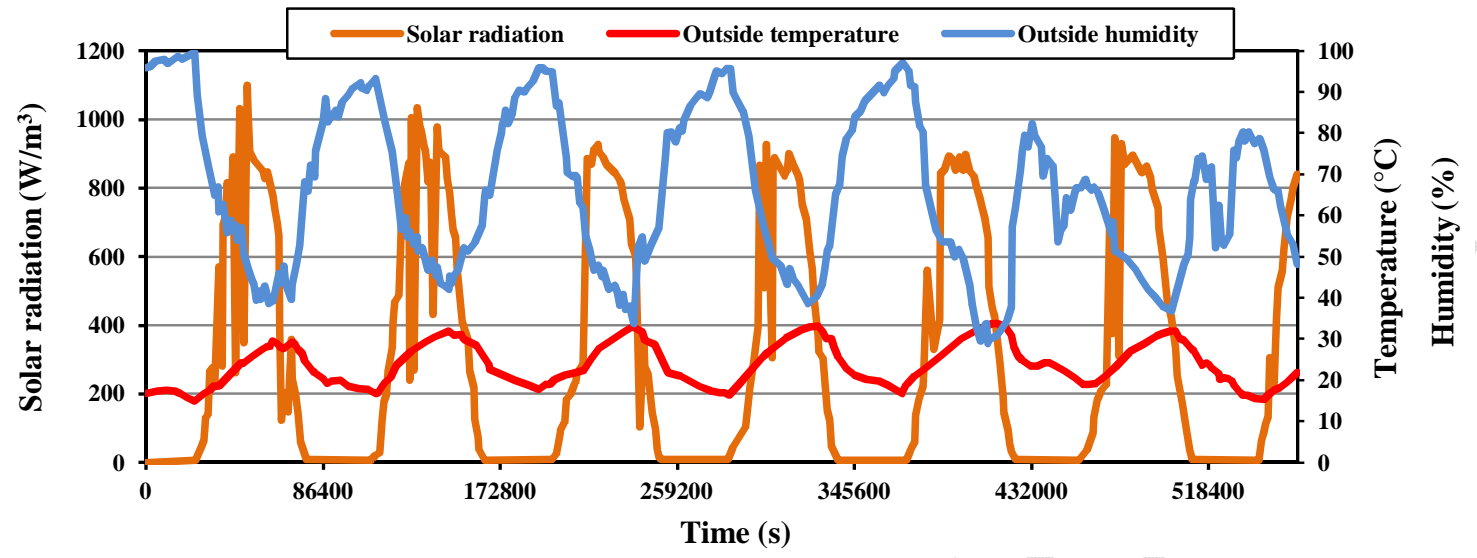

Fig. 2. Outside temperature and solar radiation as well as outside relative humidity at the beginning of July 2012 for a 6.5-day period (561600 s) in Lleida (Spain) (Coma et al. 2016).

\subsection{Green roof model with ABAQUS software}

Figs. 3(a) and 3(b) show the experimental cubicle specimen and green roof model, respectively. To realistically simulate the thermal conditions of the cubicle specimen during a 6day period on July 2011 in Lleida, the bottom of drainage layer was exposed to constant inside temperature $\left(24{ }^{\circ} \mathrm{C}=297.15 \mathrm{~K}\right.$ ), similar to what Coma et al. (2014; 2016), Pérez et al. (2012) performed. In addition, considering the edges of green roof specimens were not experimentally insulated, they could be exposed to $24^{\circ} \mathrm{C}$, similar to the bottom of green roof specimen. Therefore, the initial temperature of $24{ }^{\circ} \mathrm{C}$ was numerically considered for the edges of green roof models, similar to their bottom, even though the numerical results were extracted from the center of green roof models (Fig. 4), where was far away from the green roof's edges. On the other hand, the top of substrate was exposed to the outside temperature and solar radiation as shown in Fig. 3(b). As per the properties of different types of materials given by Pérez et al. (2012) and Coma et al. (2014; 2016), some parameters of substrate and drainage layers were introduced to ABAQUS software including the density, thermal conductivity, and specific heat value as presented in Table 1.

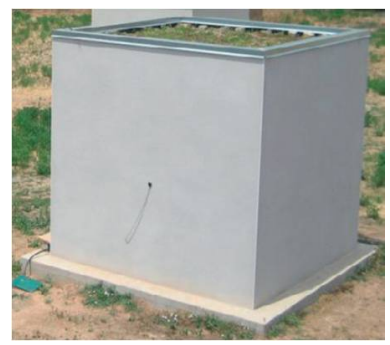

(a) 


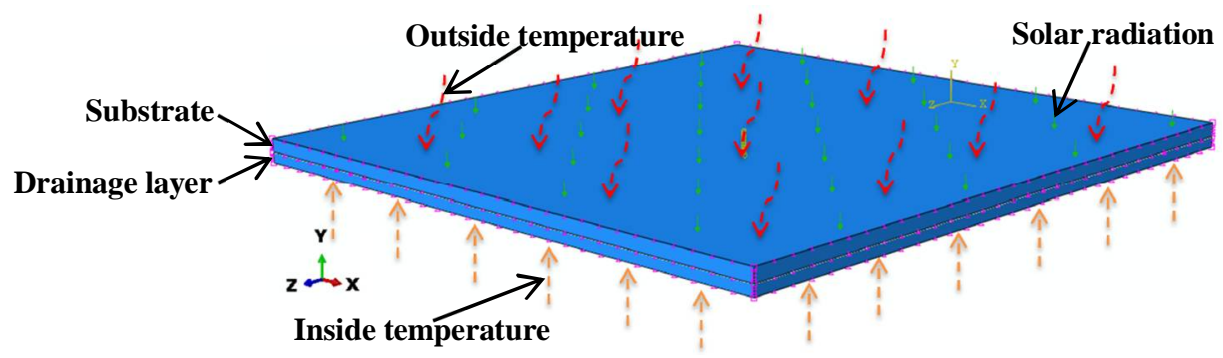

(b)

Fig. 3. Experimental cubicle of green roof (Pérez et al. 2012) (a); three-dimensional (3D) configuration of numerical model developed using ABAQUS software (b).

According to the Fig. 4, to realistically model the three-dimensional (3D) members in ABAQUS software, the 3D hexahedral element was employed as already used in other studies (Kazemi et al. 2019; Jarrah et al. 2019; Madandoust and Kazemi 2017; Mohammadi et al. 2019). The intersection between substrate and drainage layer was assumed to be the constraint of tie to effectively transfer the thermal radiation and temperature in the depth of the green roof. To verify the developed models, the fluctuation of temperature in the internal ceiling point (point A in Fig. 4) of green roofs with the drainage layer of pozzolana and rubber crumbs (P4-S5 and RC4-S5) was compared with those of experimental cubicle specimens, fabricated by Coma et al. (2014; 2016). Meanwhile, the approximate element sizes of $8 \mathrm{~cm}$ and $1 \mathrm{~cm}$ were considered for the length and depth of the green roof models as shown in Fig. 4. To assess the thermal distribution in different thicknesses of green roofs, the points A, B, C, D, E, F, G, H, I, and J were assumed along the depth of the models as depicted in Fig. 4, where the distance between the aforementioned points was the same and equal to $1 \mathrm{~cm}$.

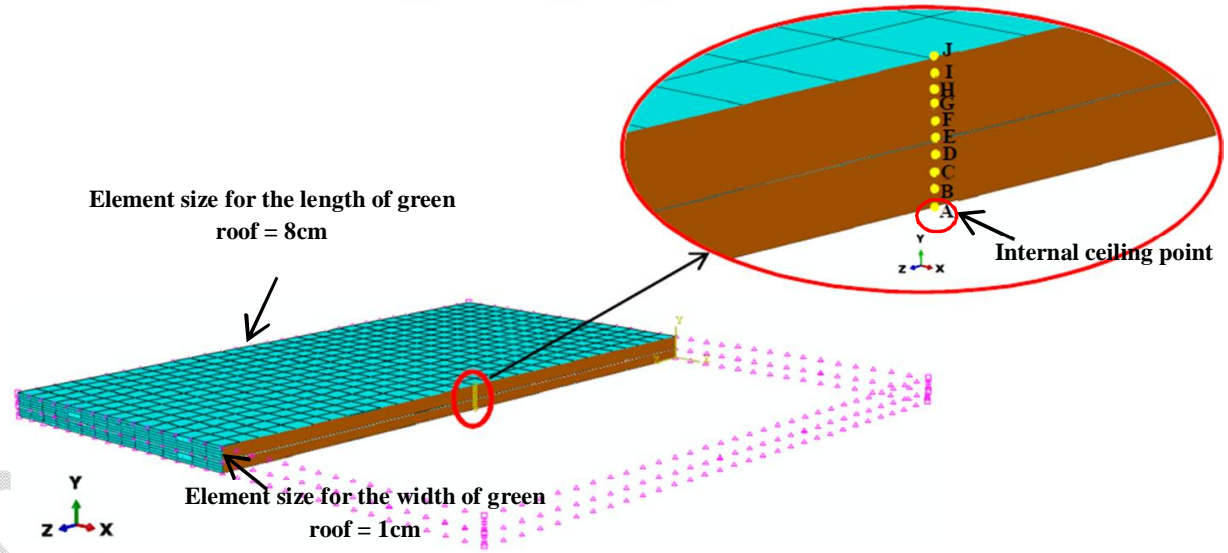

Fig. 4. Finite element mesh and cross-sectional view of green roof model.

\subsection{Green roof model with WUFI software}

Fig. 5 shows the green roof model developed using WUFI software. For the verification of green roof models, the weather conditions of Lleida for a 6-day period on July 2011 (Fig. 1) were used. In order to model the two-dimensional (2D) green roof models using WUFI software, three automatic grids were available including coarse, medium and fine. To reliably verify the green roof models, the fine gird was automatically chosen and introduced to the depth of substrate and drainage layers as shown in Fig. 5. After the verification of green roof models, the outside weather conditions of Lleida for July 2011 (Fig. 1) was replaced with those for July 2012 
(Fig. 2). To assess the simultaneous effect of thermal and humidity transfers into the depth of the green roof models, the top of substrate was exposed to the outside temperature and solar radiation as well as relative humidity (Fig. 2). On the other hand, the bottom of drainage layer was exposed to the constant inside temperature $\left(24{ }^{\circ} \mathrm{C}=297.15 \mathrm{~K}\right)$, similarly to what Coma et al. (2014; 2016) carried out experimentally.

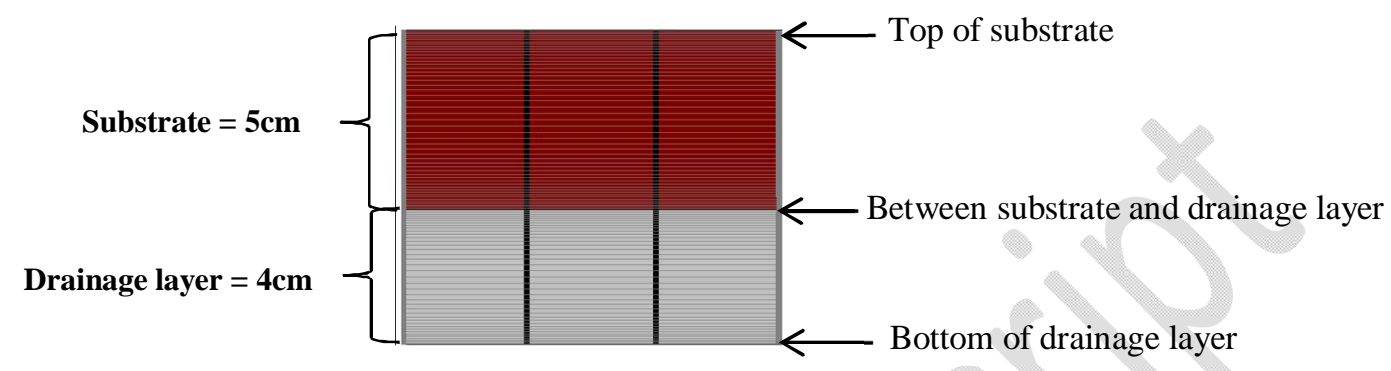

Fig. 5. 2D grid configuration of green roof model developed using WUFI software.

\section{Verification of green roof models}

For the thermal simulation using ABAQUS software, the curves of internal ceiling temperature for green roof models with the drainage layer of pozzolana and rubber crumbs were compared with those of experimental cubicle specimens under constant inside temperature, given by Pérez et al. (2012), as shown in Fig. 6. According to the Fig. 6, the temperature fluctuation for the green roof model with pozzolana as drainage layer (Analyt.(P4-S5)) was nearly the same as that obtained for the cubicle specimen (Exp.(P4-S5)). In addition, the maximum and minimum internal ceiling temperatures of the green roof model with pozzolana as drainage layer were $26.25^{\circ} \mathrm{C}$ and $23.29^{\circ} \mathrm{C}$, respectively. The corresponding values for the green roof specimen were $25.5^{\circ} \mathrm{C}$ and $23.9^{\circ} \mathrm{C}$ as reported by Pérez et al. (2012). Therefore, there was less than $2.9 \%$ difference between the results of green roof model and experimental specimen with pozzolana as drainage layer. As per Fig. 6, the variation of internal ceiling temperature for the numerical model with rubber crumbs as drainage layer (Analyt.(RC4-S5)) was found to be the same as that observed for the experimental specimen (Exp.(RC4-S5)). Moreover, the maximum and minimum internal ceiling temperatures of the green roof model with rubber crumbs as drainage layer were $25.2^{\circ} \mathrm{C}$ and $23.1^{\circ} \mathrm{C}$, respectively. The corresponding values for the green roof specimen were $24.924^{\circ} \mathrm{C}$ and $23.5^{\circ} \mathrm{C}$ as reported by Pérez et al. (2012). So, there was less than $1.7 \%$ difference between the results of green roof model and specimen with rubber crumbs as drainage layer. Generally, it can be stated that the green roof models effectively predicted the thermal behaviour of experimental cubicle specimens, tested by Pérez et al. (2012).

To verify the green roof model using WUFI software, a comparison between the internal ceiling temperature of experimental specimens given by Pérez et al. (2012) and green roof models was performed as shown in Fig. 6. According to the results, the fluctuation of internal ceiling temperature for the green roof models was nearly the same as that for the green roof specimens. Also, the maximum and minimum internal ceiling temperatures of the green roof model with pozzolana as drainage layer were $25.5^{\circ} \mathrm{C}$ and $23.5^{\circ} \mathrm{C}$, respectively. In addition, the maximum and minimum internal ceiling temperatures of the green roof model with rubber crumbs as drainage layer were $25.17^{\circ} \mathrm{C}$ and $23.03^{\circ} \mathrm{C}$, respectively. Therefore, there was less than $2.1 \%$ difference between the results of green roof models and experimental specimens given by Pérez et al. (2012). It can be stated that the thermal behaviour of green roof model suitably agreed with the experimental results given by Pérez et al. (2012). 


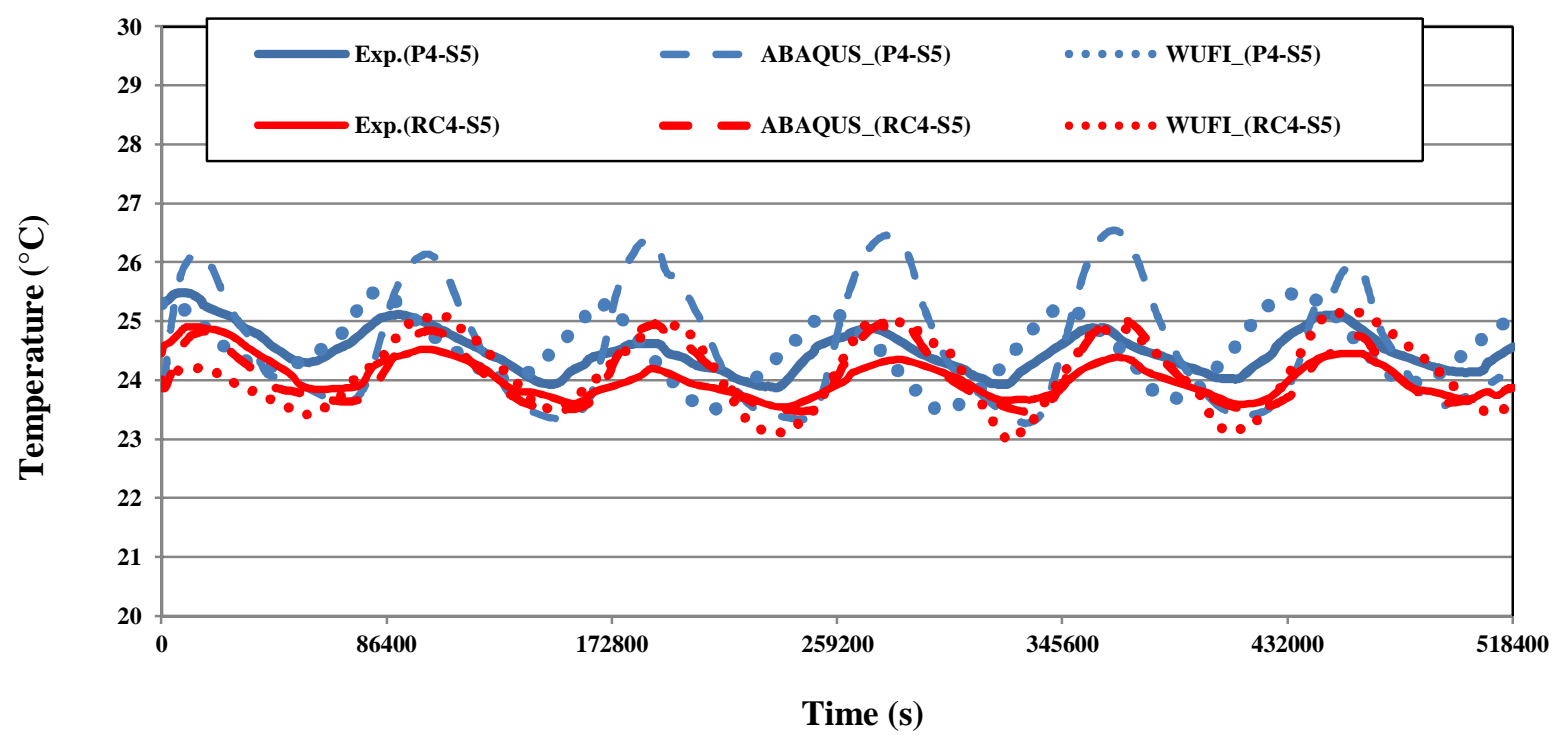

Fig. 6. A comparison between the internal ceiling temperature of experimental green roof specimens and green roof models.

\section{Results and discussions}

\subsection{Thermal performances}

Fig. 7 shows the ceiling temperature in different depths of the green roof model with the drainage layer of pozzolana (P4-S5) and rubber crumbs (RC4-S5), which were modelled using ABAQUS software. The data were presented in terms of each $1 \mathrm{~cm}$ through the depth of green roof layers to accurately assess the temperature distribution through the depth of different layers. According to the results, an approximate linear increase in temperature was observed for each layer at a specific time. 


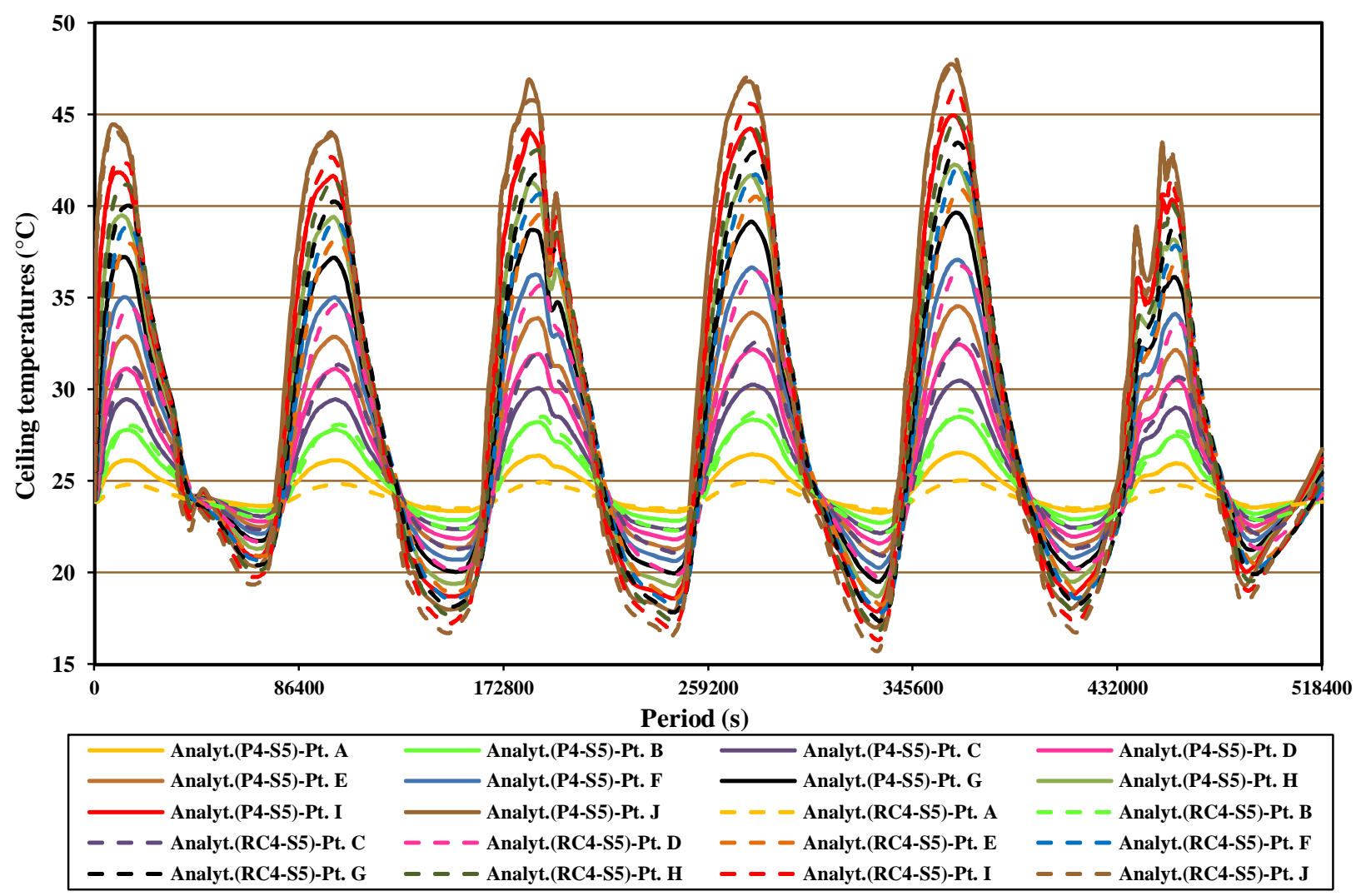

Fig. 7. Ceiling temperature vs. period plot of green roof for the points of A, B, C, D, E, F, G, H, I, and J, shown in Fig. 4.

In Fig. 7, Analyt. (P4-S5)- Pt. A, Analyt. (P4-S5)- Pt. B, Analyt. (P4-S5)- Pt. C, and Analyt. (P4-S5)- Pt. D are the fluctuation of temperature in the points A, B, C, and D, respectively, at the same order shown in Fig. 4, indicating the temperature in different depths of the pozzolana as drainage layer. Analyt. (P4-S5)- Pt. E, Analyt. (P4-S5)- Pt. F, Analyt. (P4-S5)- Pt. G, Analyt. (P4-S5)- Pt. H, Analyt. (P4-S5)- Pt. I, and Analyt. (P4-S5)- Pt. J are the fluctuation of temperature in the points E, F, G, H, I, and J, respectively, at the same order as shown in Fig. 4, depicting the variation of temperature in different depths of the substrate. As indicated in Fig. 4, the maximum and minimum temperatures at the top of green roof (Analyt. (P4-S5)- Pt. J) were $47.74^{\circ} \mathrm{C}$ and $17.02^{\circ} \mathrm{C}$, respectively. The corresponding values at the bottom of green roof (Analyt. (P4-S5)- Pt. A) were $26.5^{\circ} \mathrm{C}$ and $23.29^{\circ} \mathrm{C}$, respectively. Therefore, the results showed that the fluctuation of temperature from the surface to the bottom of green roof decreased, leading to decreasing the internal ceiling temperature variation. This process demonstrated that the substrate and drainage layers resisted the outside temperature fluctuation to transfer through green roof systems, which led to declining the diurnal temperature variation at lower layers of green roof model as explained by Parizotto and Lamberts (2011). In addition, the results showed that the fluctuation of temperature in the substrate was obtained more than that in the pozzolana as drainage layer as shown in Fig. 7.

Similar to what was observed for the green roof with the pozzolana as drainage layer, the fluctuation of temperature in the substrate was obtained more than that in the drainage layer of rubber crumbs. However, the fluctuation of temperature in the drainage layer of rubber crumbs was more than that of pozzolana. In this regard, the contour plots of green roof with pozzolana 
(P4-S5) and rubber crumbs (RC4-S5) as drainage layer were compared to each other in Figs. 8(a) and $8(\mathrm{~b})$, when the maximum nodal temperature distribution was generated in $370000^{\text {th }} \mathrm{s}$. As per the results, the temperatures at the top and bottom of pozzolana as drainage layer were found to be $304.6 \mathrm{~K}$ and $299.5 \mathrm{~K}$, respectively (Fig. 8(a)). The corresponding values for the rubber crumbs as drainage layer were $311.6 \mathrm{~K}$ and $298.2 \mathrm{~K}$, respectively, as indicated in Fig. 8(b). Concerning this, the temperature at the top of pozzolana layer was $1.7 \%$ more than its bottom surface. The corresponding difference for the rubber crumbs as drainage layer was $4.5 \%$. Therefore, it can be stated that the rubber crumbs outperformed pozzolana to prevent transferring the temperature to green roof systems, owing to lower bulk density of rubber crumbs, leading to generating more air gaps in the green roof, and subsequently increasing the thermal resistance of system (Coma et al. 2014; Pérez et al. 2012; Saberian et al. 2019; Akbarzadeh Bengar et al. 2020).

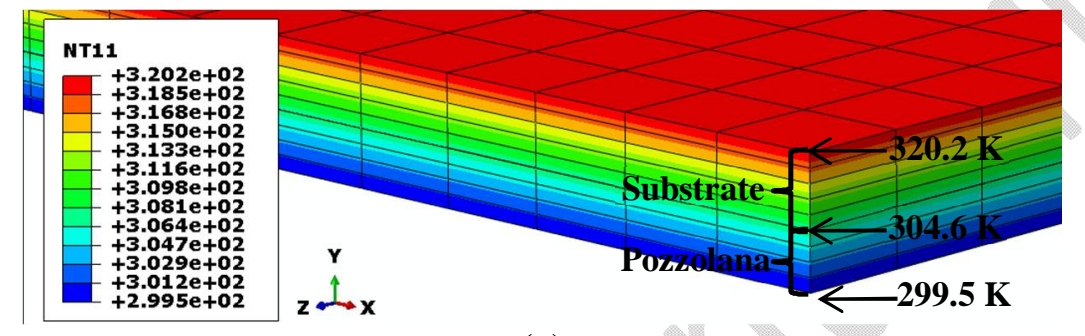

(a)

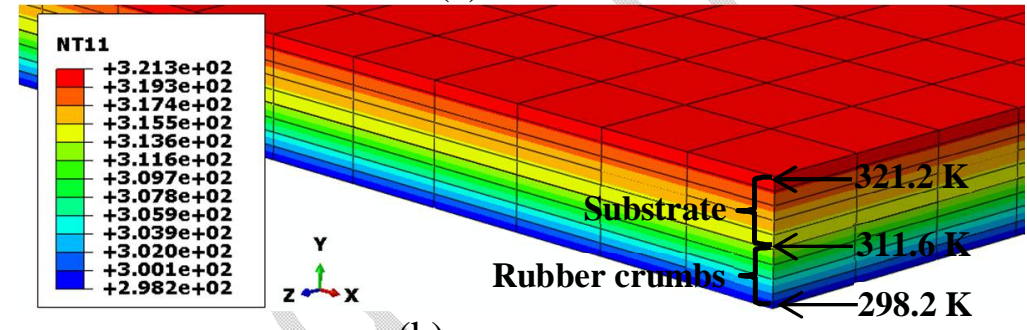

(b)

Fig. 8. The maximum nodal temperature distribution in the green roofs under constant inside temperature with drainage layer of pozzolana (P4-S5 ) (a); and rubber crumbs (RC4-S5 ) (b); the

\subsection{Parametric study} unit in the legends is $\mathrm{K}$.

\subsubsection{Thickness of substrate}

By keeping constant the thickness of drainage layer $(4 \mathrm{~cm})$, the fluctuation of internal ceiling temperature for the green roof models with different thicknesses of substrate is shown in Fig. 9. According to the results, the fluctuation of temperature decreased by increasing the thickness of substrate from $5 \mathrm{~cm}$ to $10 \mathrm{~cm}$ as expected. However, this fluctuation for the green roofs with drainage layer of pozzolana was found to be more than those of rubber crumbs. Regarding this, the temperatures at the top and bottom of substrate layer are presented in Fig. 10 to compare the effect of drainage layer type on the thermal distribution in the substrate. For the green roofs with the pozzolana material, the temperature at the top of the substrate was in the range from $320.2 \mathrm{~K}$ to $320.9 \mathrm{~K}$. The corresponding value at the bottom of substrate was in the 302.3-304.6 K range. On the other hand, for the green roofs with the rubber crumbs, the temperature at the top of the substrate was in the range from $320.2 \mathrm{~K}$ to $321.4 \mathrm{~K}$. The corresponding value at the bottom of substrate was in the 305.6-311.6 K range. Therefore, the temperature at the top of the substrate was on average about $5.54 \%$ more than that at the bottom of the substrate for the green roof with 
the pozzolana material. The corresponding difference was $4.14 \%$ for the green roof with the rubber crumbs. It can be stated that the thermal performance of substrate was slightly affected by the type of materials used for the drainage layer similarly to what Cascone (2019) concluded and the drainage layer of rubber crumbs outperformed that of pozzolana to prevent transferring the temperature to green roof systems, owing to lower bulk density of rubber crumbs in comparison to the pozzolana material.

As shown in Fig. 10, the difference between the temperature at the top and bottom of substrate increased by increasing the thickness of substrate, which led to increasing the thermal resistance of green roof. However, for the green roof either with pozzolana or rubber crumbs as drainage layer, this difference for substrate with the thicknesses of $9 \mathrm{~cm}$ and $10 \mathrm{~cm}$ was negligible. From the structural point of view, it would be better to choose the low-weight substrate layers, imposing a lower load to the building (Teemusk and Mander 2009; Sadeghian et al., 2020). Therefore, the substrate with the thickness of $9 \mathrm{~cm}$ is recommended to be used once the thickness of pozzolana and rubber crumbs as drainage layer is kept constant, equal to $4 \mathrm{~cm}$.

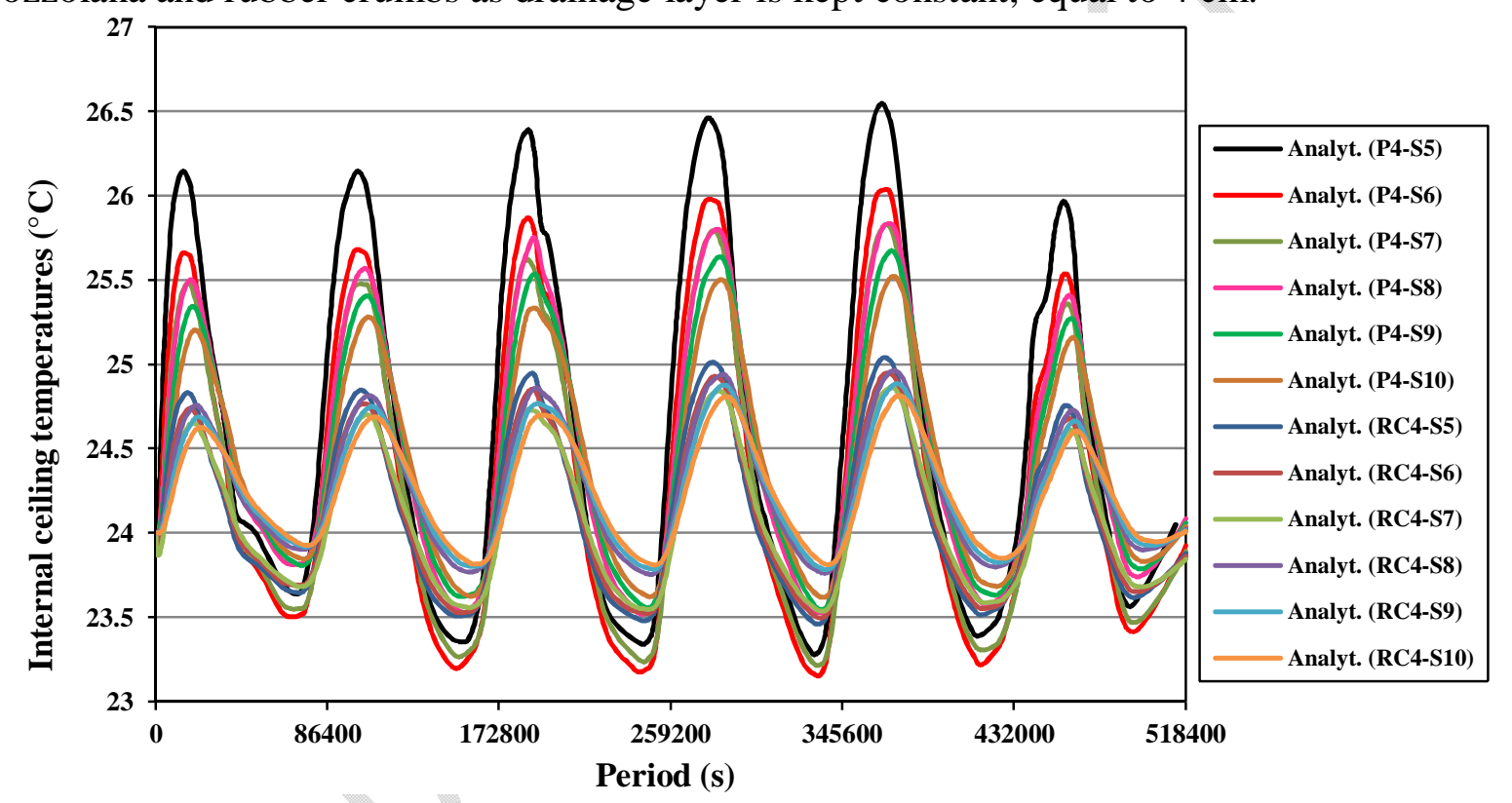

Fig. 9. Internal ceiling temperature (point A in Fig. 4) in the green roofs with different thicknesses of substrate. 


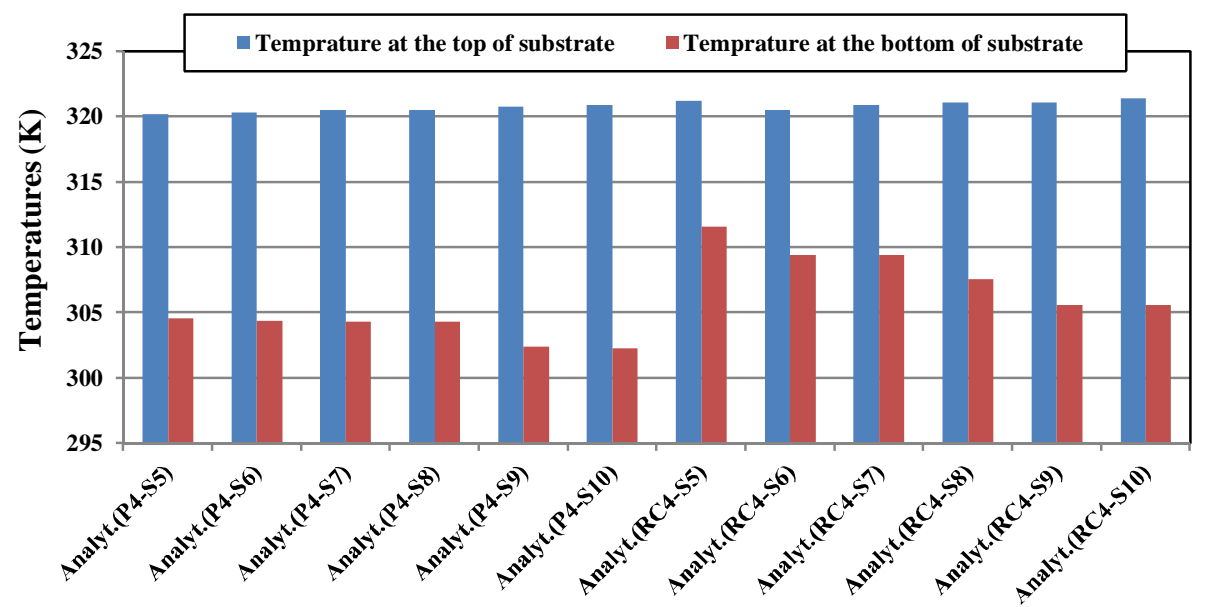

Fig. 10. The maximum nodal temperature (generated about $370000^{\text {th }} \mathrm{s}$ ) in the green roofs with different thicknesses of substrate.

\subsubsection{Thickness of drainage layer}

Fig. 11 shows the fluctuation of internal ceiling temperature for the green roof models with different thicknesses of drainage layer by keeping constant the thickness of substrate $(5 \mathrm{~cm})$. According to the results, the fluctuation of temperature decreased by increasing the thickness of drainage layer from $4 \mathrm{~cm}$ to $8 \mathrm{~cm}$. In addition, the internal ceiling temperature fluctuated more in the green roof with pozzolana than that with rubber crumbs. Although both rubber crumbs and pozzolana had high porosity, low bulk density of rubber crumbs led to increasing the air entrapment into the drainage layer and generating higher resistance to the temperature transfer through green roof systems similarly to what Coma et al. (2014) and Pérez et al. (2012) concluded.

The temperatures at the top and bottom of drainage layer of pozzolana and rubber crumbs are presented in Fig. 12. The results showed that the temperature at the top of the pozzolana layer was in the range from $304.6 \mathrm{~K}$ to $310.1 \mathrm{~K}$. The corresponding value at the bottom of substrate was in the 298.8-299.5 K range. Furthermore, the temperature at the top of the rubber crumbs layer was in the range from $311.6 \mathrm{~K}$ to $316.7 \mathrm{~K}$. The corresponding value at the bottom of the rubber crumbs layer was in the $297.8-298.2 \mathrm{~K}$ range. In other words, the temperature at the top of the pozzolana layer was on average about $3.11 \%$ more than that at its bottom surface. The corresponding difference for the drainage layer of rubber crumbs was $5.74 \%$. Therefore, it can be stated that the pozzolana and rubber crumbs resisted against the thermal transfer through the inside of the green roof, similarly to what Coma et al. (2014; 2016) and Mohammed et al. (2012) observed. However, due to higher diffusion properties of rubber crumbs than pozzolana, the thermal distribution along the depth of rubber crumbs as drainage layer was found to be more.

As per the results, by increasing the thickness of drainage layer, the difference between the temperature at the top and bottom of the drainage layer in the green roof models increased (Fig. 12). However, there was no significant difference between the results of the drainage layer of pozzolana with the thicknesses of $6 \mathrm{~cm}, 7 \mathrm{~cm}$, and $8 \mathrm{~mm}$. The same was observed for the drainage layer of rubber crumbs with of $7 \mathrm{~cm}$ and $8 \mathrm{~cm}$. For instance, the difference between the temperature at the top and bottom of the drainage layer of pozzolana with the thicknesses of $6 \mathrm{~cm}, 7 \mathrm{~cm}$, and $8 \mathrm{~cm}$ was in the range of 10.9-11.2 K. The corresponding difference for the 
drainage layer of rubber crumbs with the thicknesses of $7 \mathrm{~cm}$ and $8 \mathrm{~cm}$ was in the $18.5-18.9 \mathrm{~K}$ range. Since it has been recommended to select the low-weight drainage layers for the extensive green roof (Oberndorfer et al. 2007; Raji et al. 2015), the $6 \mathrm{~cm}$ and $7 \mathrm{~cm}$ can be considered as optimum thicknesses for the drainage layers of pozzolana and rubber crumbs, respectively.

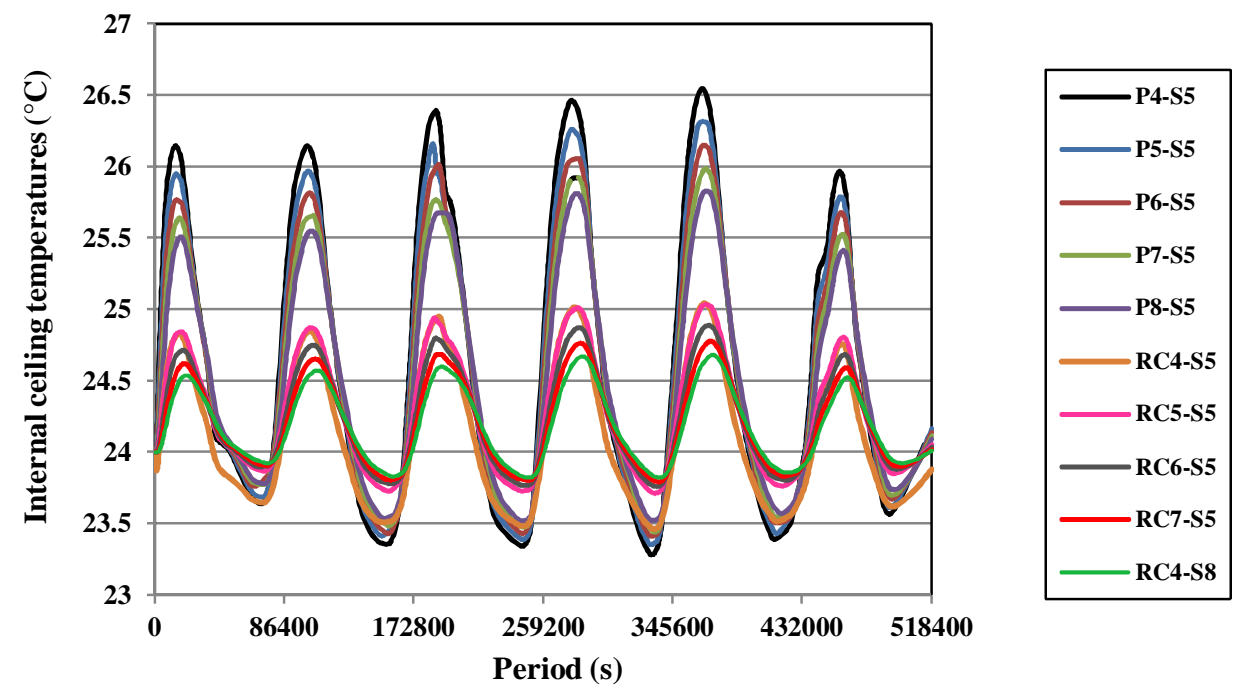

Fig. 11. Internal ceiling temperature (point A in Fig. 4) in the green roofs with different thicknesses of drainage layer.

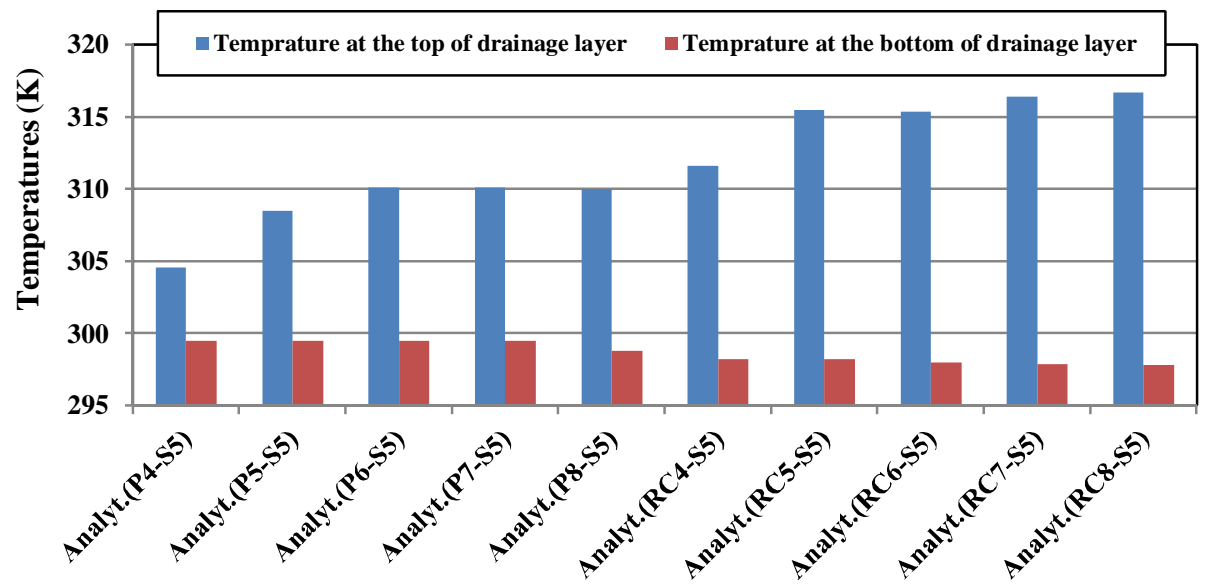

Fig. 12. The maximum nodal temperature (generated about $370000^{\text {th }} \mathrm{s}$ ) in the green roofs with different thicknesses of drainage layer.

\subsection{Effects of humidity and temperature on thermal performances}

In this section, the WUFI software was used to assess the integration of temperature and humidity transfer in the P4-S5 and RC4-S5 models at the top and bottom of green roof and between substrate and drainage layers during summer period as shown in Figs. 13 and 14. According to the results, the temperature at the top of green roof with the drainage layer of pozzolana and rubber crumbs was in the range of $16.44-31.89{ }^{\circ} \mathrm{C}$ and $16.07-32.25{ }^{\circ} \mathrm{C}$, respectively. The corresponding values between the substrate and drainage layer of green roof with pozzolana and rubber crumbs were $19.44-28.59{ }^{\circ} \mathrm{C}$ and $18.07-30.07{ }^{\circ} \mathrm{C}$. The ranges of 
21.12-26.86 ${ }^{\circ} \mathrm{C}$ and $22.27-25.73^{\circ} \mathrm{C}$ were obtained for the bottom of green roof with the drainage layer of pozzolana and rubber crumbs, respectively. It can be stated that the fluctuation of temperature decreased from the top to the bottom of green roof demonstrating suitable heat resistance of substrate and drainage layer of pozzolana and rubber crumbs. In addition, the fluctuation of temperature at the bottom of green roof with the drainage layer of rubber crumbs was slightly lower than that of pozzolana. It can be due to lower bulk density rubber crumbs than that of pozzolana, leading to increasing the thermal performance of system (Coma et al. 2016; Pérez, et al. 2012). As mentioned by Coma et al. (2016), the comfort temperature for the inside of houses was in the $23-26^{\circ} \mathrm{C}$ range, particularly during summer period. The ranges of internal ceiling temperature of green roof with the drainage layer of pozzolana and rubber crumbs (temperature at the bottom of green roof) were near to the same range as reported by Coma et al. (2016). That's why the current design of green roof could provide the required internal comfort temperatures, particularly during summer period.

The relative humidity at the top of green roof with the drainage layer of pozzolana and rubber crumbs was in the range of 33.27-86.09\% and 32.46-87.1\%, respectively. The corresponding values between the substrate and drainage layer of green roof with pozzolana and rubber crumbs were $41.13-79.64 \%$ and $37.78-83.23 \%$. The ranges of $44.96-74.6 \%$ and $45.16-71.57 \%$ were obtained for the bottom of green roof with the drainage layer of pozzolana and rubber crumbs, respectively. The range of internal relative humidity for comfort is about $30-70 \%$ as reported by other researchers (Tsutsumi et al. 2007; Jin et al. 2017; fan et al. 2019). Therefore, the ranges of internal relative humidity (humidity at the bottom of drainage layer of pozzolana and rubber crumbs) were within the humidity range for indoor comfort. In addition, the results showed that the relative humidity of green roof decreased from the top to the bottom the green roof, demonstrating the suitable water absorption capacity of substrate and drainage layer.

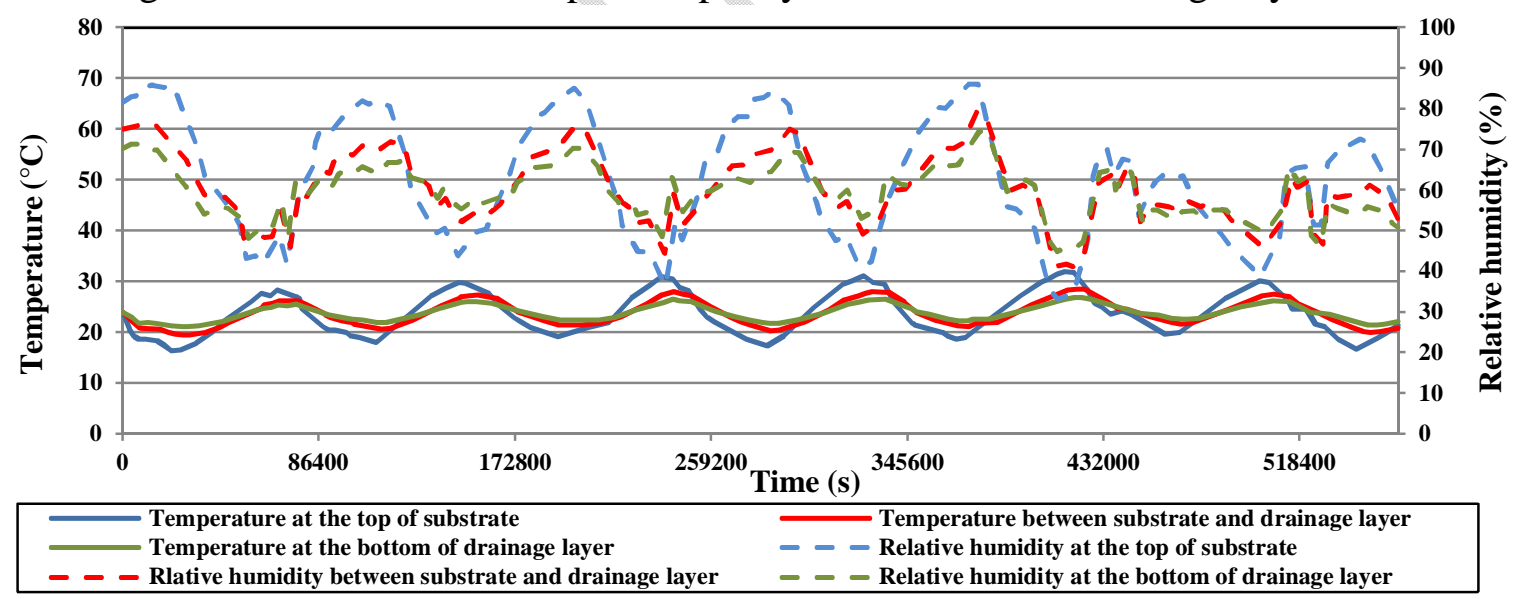

Fig. 13. The temperature and humidity fluctuation in different depths of green roof model with drainage layer of pozzolana (P4-S5) under constant inside temperature. 


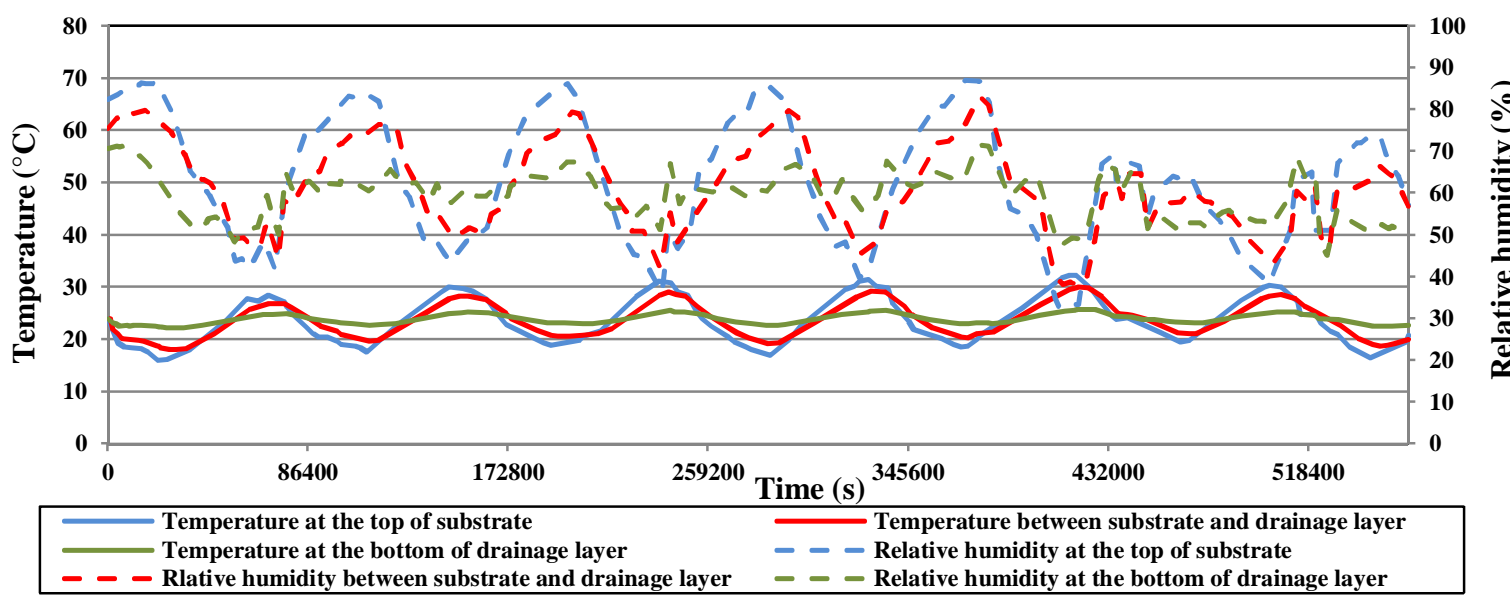

Fig. 14. The temperature and humidity fluctuation in different depths of green roof model with drainage layer of rubber crumbs (RC4-S5) under constant inside temperature.

\subsection{Sensitivity analysis 4.4.1. Thickness of substrate}

Figs. 15 and 16 show the integration of internal ceiling temperature and humidity fluctuation for the green roof models with different thicknesses of substrate once the thickness of drainage layer was kept constant $(4 \mathrm{~cm})$. By using the pozzolana as drainage layer, the range of internal ceiling temperature for the green roof models with 5-, 6-, 7-, 8-, 9- and 10-cm substrate was 21.12-26.86 ${ }^{\circ} \mathrm{C}, 21.32-26.61{ }^{\circ} \mathrm{C}, 21.5-26.37{ }^{\circ} \mathrm{C}, 21.67-26.2{ }^{\circ} \mathrm{C}, 21.8-26.05^{\circ} \mathrm{C}$, and $21.93-25.87$ ${ }^{\circ} \mathrm{C}$, respectively, as shown in Fig. 15. The corresponding values for the green roof models with the drainage layer of rubber crumbs were $22.27-25.73{ }^{\circ} \mathrm{C}, 22.35-25.62{ }^{\circ} \mathrm{C}, 22.45-25.52{ }^{\circ} \mathrm{C}$, $22.53-25.43^{\circ} \mathrm{C}, 22.61-25.31^{\circ} \mathrm{C}$, and $22.68-25.2^{\circ} \mathrm{C}$ as shown in Fig. 16. The results showed that the ranges of internal ceiling temperature of green roof models with different thicknesses of substrate were nearly within the range of $23-26{ }^{\circ} \mathrm{C}$, which is the comfort temperature for the inside of houses during summer period as reported by Coma et al. (2016).

The internal relative humidity values for the green roof models with different thicknesses of substrate were between $44.56 \%$ and $73.59 \%$ as indicated in Figs. 15 and 16. These values were nearly within the range of $30-70 \%$, which is the comfort humidity for the inside of houses as reported by other researchers (Tsutsumi et al. 2007; Jin et al. 2017; fan et al. 2019). On the other hand, the results showed that the fluctuation of relative humidity increased by increasing the temperature, while the reverse was observed by decreasing the temperature. This process showed that high temperature caused to evaporate the water content in the substrate layer, which somewhat prevented the transfer of outside temperature and solar radiation through the depth of green roof system.

According to the results, the fluctuation of internal ceiling temperature in the green roof models with the presence of humidity (Figs. 15 and 16) decreased by increasing the thickness of substrate, but not as much as those without the presence of humidity (Fig. 9). However, once there was the humidity in different layers of green roof during summer period, increasing the temperature led to the evaporation of water content in substrate layer. This evaporated water participated in absorbing some parts of the outside temperature and solar radiation. That's why 
the fluctuation of internal ceiling temperature slightly decreased by increasing the thickness of substrate once there was the humidity in the substrate layer.

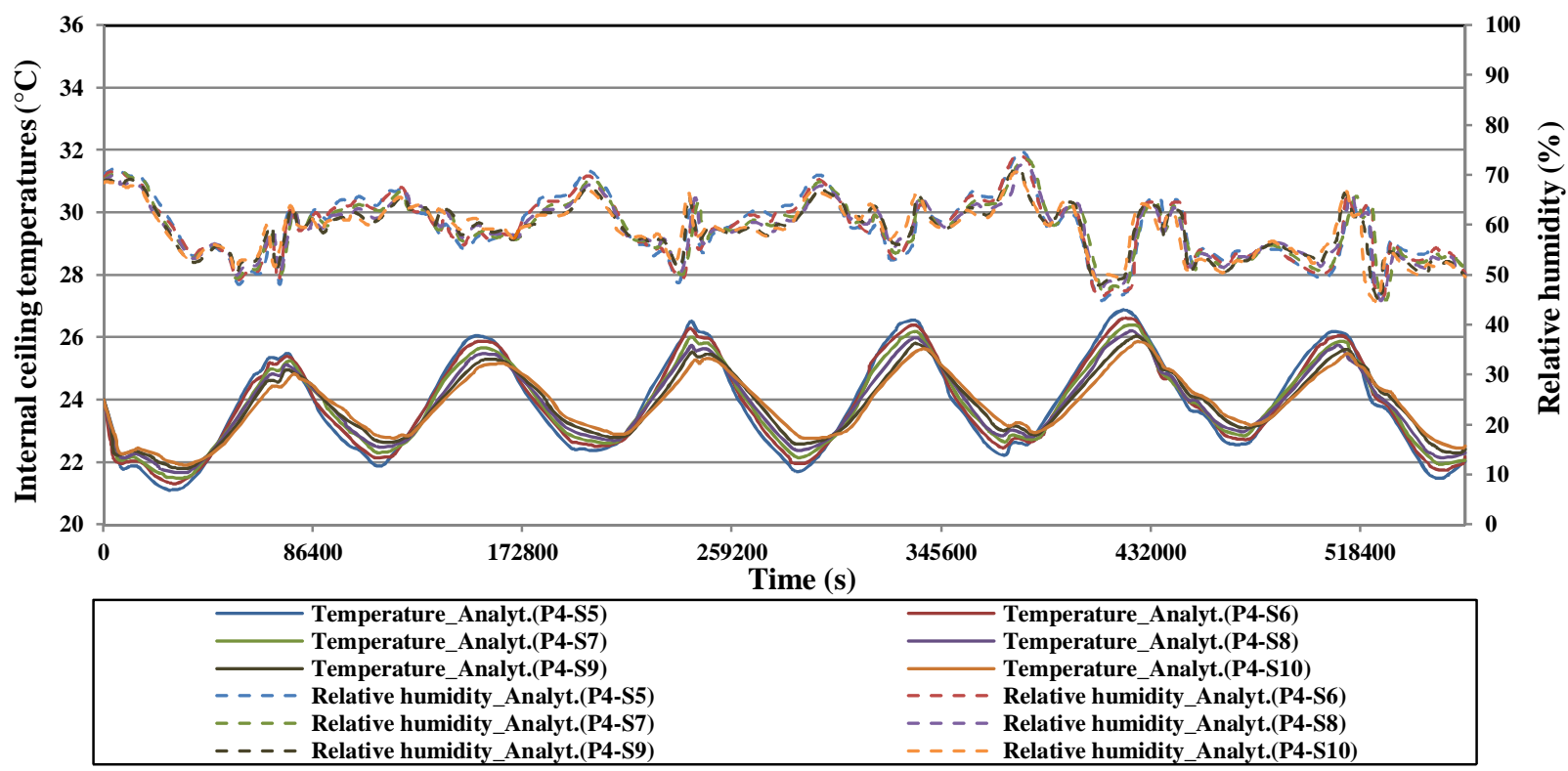

Fig. 15. The internal ceiling temperature and humidity fluctuation for the green roof models with the drainage layer of pozzolana and different thicknesses of substrate.

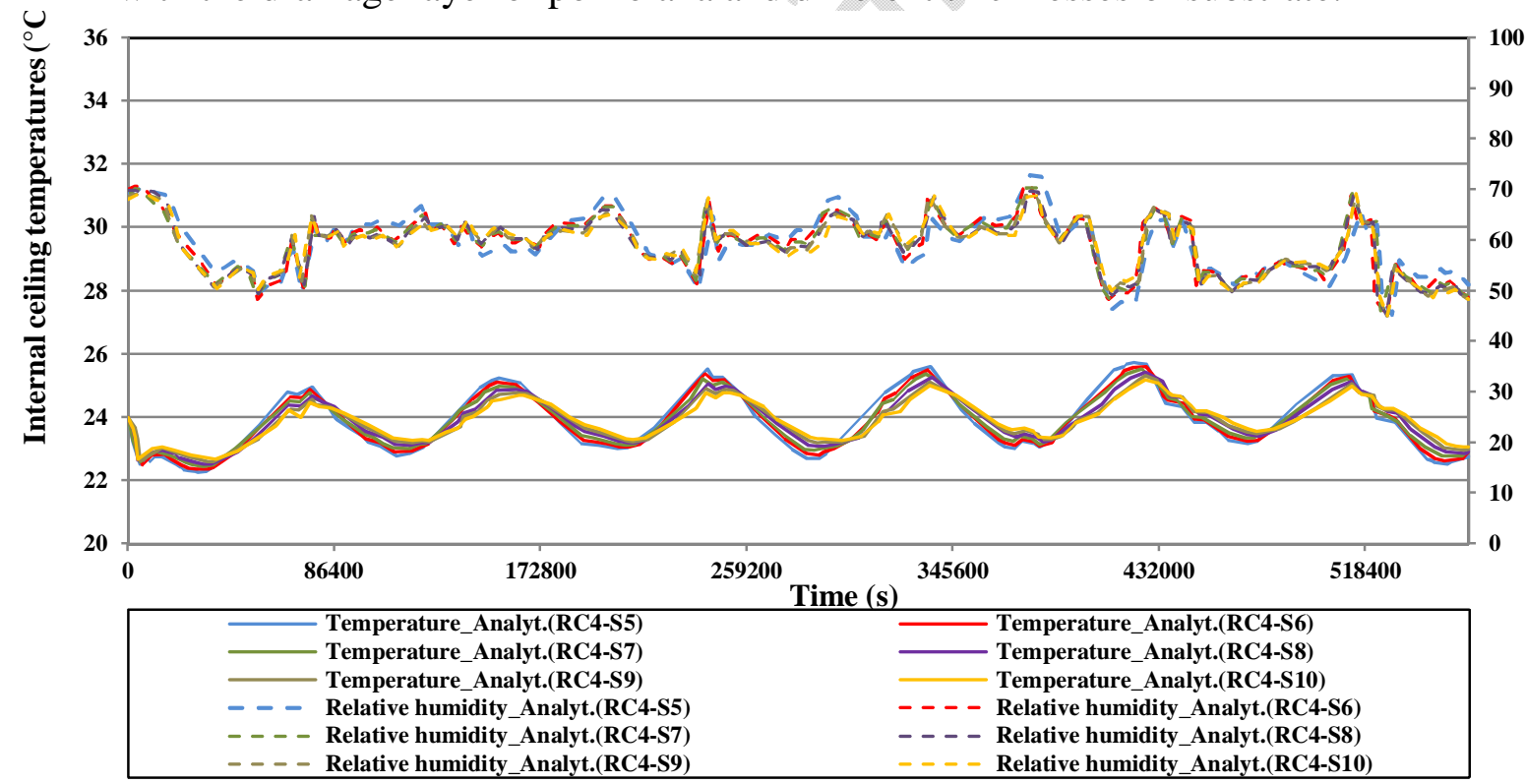

Fig. 16. The internal ceiling temperature and humidity fluctuation for the green roof models with drainage layer of rubber crumbs and different thicknesses of substrate.

\subsubsection{Thickness of drainage layer}

The integration of internal ceiling temperature and humidity fluctuation for the green roof models with different thicknesses of drainage layer of pozzolana and rubber crumbs is shown in Figs. 17 and 18. According to Fig. 17, the range of internal ceiling temperature for the green roof models with 4-, 5-, 6-, 7-, and 8-cm drainage layer of pozzolana was $21.22-26.86{ }^{\circ} \mathrm{C}, 21.24-$ 
26.68 ${ }^{\circ} \mathrm{C}, 21.38-26.5{ }^{\circ} \mathrm{C}, 21.47-26.34{ }^{\circ} \mathrm{C}$, and $21.57-26.23{ }^{\circ} \mathrm{C}$, respectively. The corresponding values for the green roof models with the drainage layer of rubber crumbs were $22.4-25.73{ }^{\circ} \mathrm{C}$, 22.46-25.52 ${ }^{\circ} \mathrm{C}, 22.5-25.4{ }^{\circ} \mathrm{C}, 22.53-25.26{ }^{\circ} \mathrm{C}$, and $22.52-25.14{ }^{\circ} \mathrm{C}$ as shown in Fig. 18. According to the results, there was no significant difference between the range of internal ceiling temperature of green roof models with different thickness of drainage layer and that of comfort temperature $\left(23-26{ }^{\circ} \mathrm{C}\right)$ reported by Coma et al. (2016). The fluctuation of internal ceiling temperature of green roof model with the rubber crumbs was slightly lower than that with pozzolana due to higher diffusive properties and lower bulk density of rubber crumbs in comparison to the pozzolana material (Coma et al. 2016; Pérez et al. 2012).

As shown in Figs. 17 and 18, the relative humidity values for the green roof models with different thicknesses of substrate were between $45.05 \%$ and $73.79 \%$. These values were nearly within the range of $30-70 \%$, which is the humidity range for indoor comfort (Tsutsumi et al. 2007; Jin et al. 2017; fan et al. 2019). In most cases, there was a rapid fluctuation in relative humidity once the temperature increased. This process can be attributed to the evaporation of water content in the substrate layer, which directly affected the heat transfer within green roof systems, similar to what Li and Zhu (2003) reported.

Generally, the fluctuation of internal ceiling temperature in the green roof models with the presence of humidity (Figs. 17 and 18) decreased by increasing the thickness of drainage layer, but not as much as that without the presence of humidity (Fig. 11). It can be due to the fact that the pozzolana and rubber crumbs used for the drainage layer of green roof had high water retention capacity (Coma et al. 2016; Vila et al. 2012). The trapped water in the drainage layer was evaporated by increasing the temperature during summer period. This process absorbed some parts of the outside temperature and solar radiation, leading to a moderate decrease in the internal ceiling temperature by increasing the thickness of substrate once there was the humidity in the drainage layer.

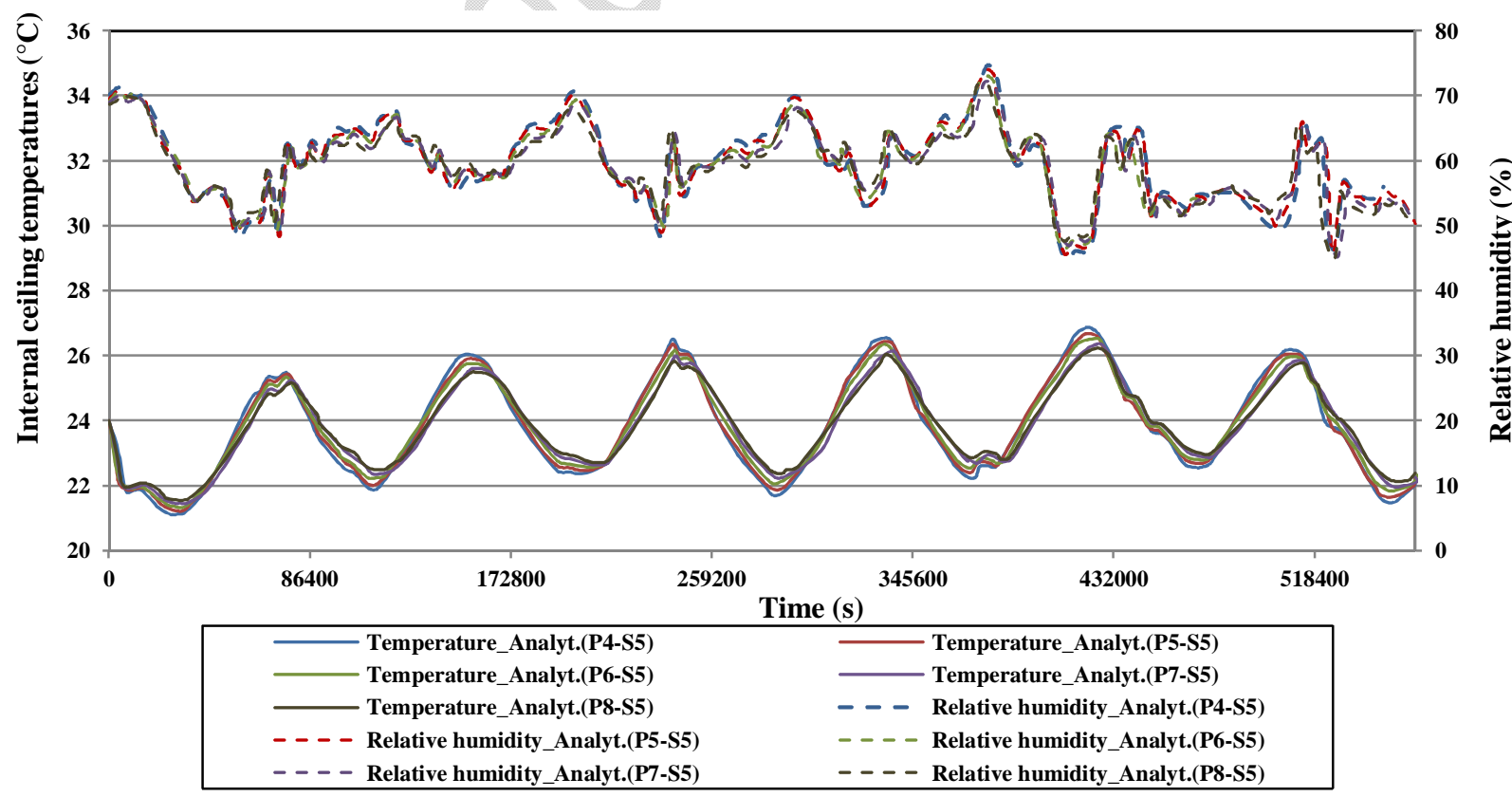

Fig. 17. The internal ceiling temperature and humidity fluctuation for the green roof models with different thicknesses of the drainage layer of pozzolana. 


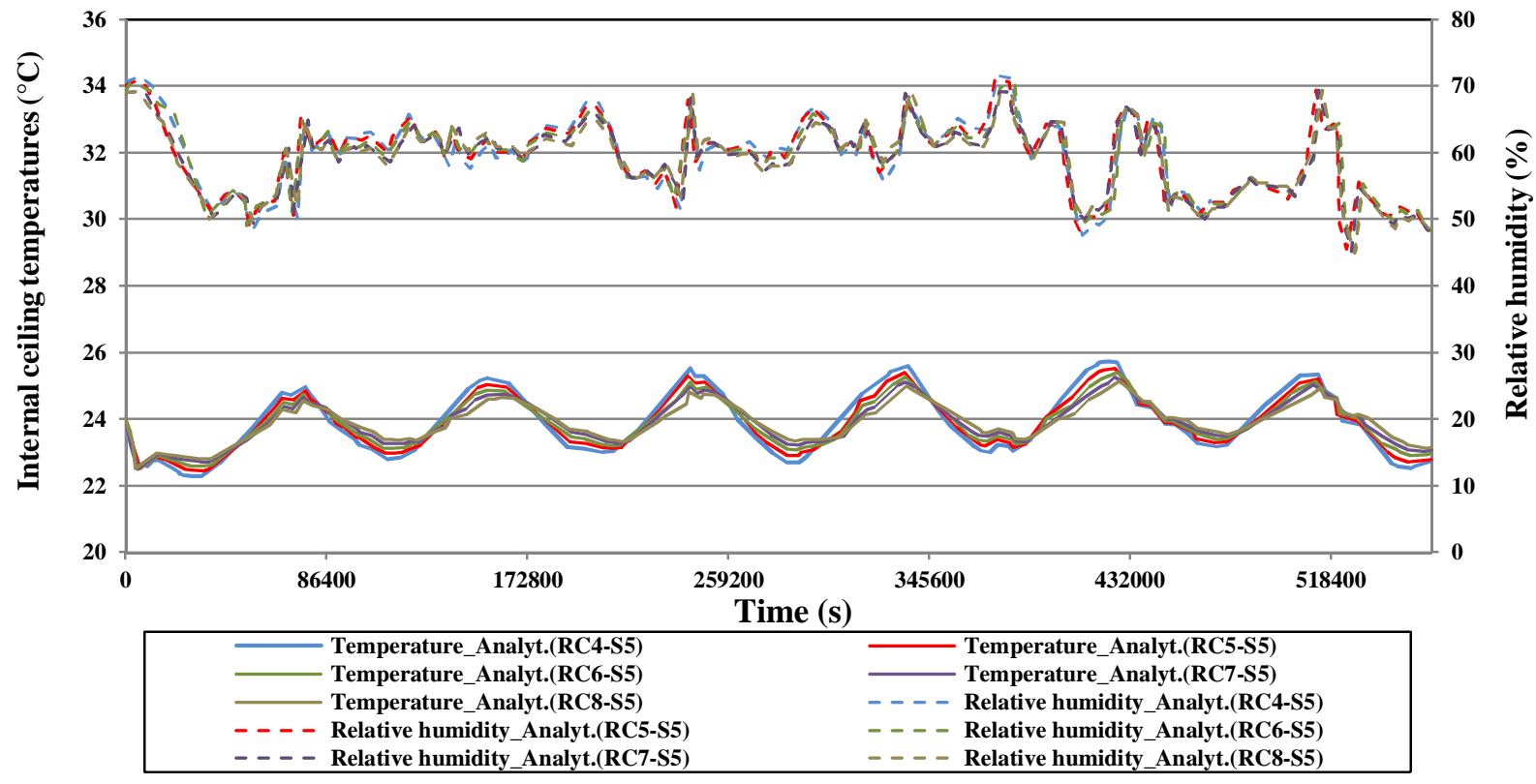

Fig. 18. The internal ceiling temperature and humidity fluctuation for the green roof models with different thicknesses of the drainage layer of rubber crumbs.

\section{Conclusions}

In this study, the behavior of specific rubber crumbs and volcanic gravel as drainage layer has been simulated on the base of the temperature and humidity transfers within green roof systems, the thickness of substrate and drainage layer was optimized and adapted for dry summer, Mediterranean climate with low precipitation. According to the developments, the following conclusions can be drawn:

- The modeling realistically predicted the thermal performances observed on experimental cubicle specimens. In addition, the temperature fluctuation in the substrate was observed to be more than that in the drainage layer made of rubber crumbs and pozzolana. Furthermore, this fluctuation in the rubber crumbs was lower than in pozzolana material.

- By keeping constant the thickness of the drainage layer, an increase in the thickness of substrate from $5 \mathrm{~cm}$ to $10 \mathrm{~cm}$ caused a decrease of the fluctuation of internal ceiling temperature once there was no humidity in green roofs. In addition, the temperature at the top of the substrate was on average about $5.54 \%$ and $4.14 \%$ higher than that at the bottom of the substrate for the green roofs with the pozzolana and rubber crumbs, respectively, once the thickness of the drainage layer was constant. Therefore, the heat resistance with rubber crumbs was moderately more important than those with pozzolana. On the other hand, the 9-cm substrate was recommended to be used for the green roofs once the thickness of the drainage layer was kept constant.

- By keeping constant the thickness of the substrate, the fluctuation of temperature decreased by increasing the thickness of drainage layer from $4 \mathrm{~cm}$ to $8 \mathrm{~cm}$ once there was no humidity in green roofs. In addition, the internal ceiling temperature of green roof with pozzolana fluctuated more than that of the green roof with rubber crumbs. Meanwhile, the temperature at the top of the pozzolana and rubber crumbs as the drainage layer was on average about $3.11 \%$ and $5.74 \%$, respectively, more than that at 
their bottom surface. It is worth noting that the optimum thickness of pozzolana and rubber crumbs as drainage layer was $6 \mathrm{~cm}$ and $7 \mathrm{~cm}$, respectively, once the thickness of the substrate was kept constant.

- The simultaneous heat and moisture transfers within the green roof models showed that there was no significant difference between the range of internal ceiling temperature of green roof models with different thickness of substrate and drainage layers and that of comfort temperature. In addition, by increasing the thickness of substrate and drainage layers, the fluctuation of internal ceiling temperature in the green roof models with the presence of humidity decreased, but not as much as that in the green roof models without the presence of humidity.

\section{Conflict of Interest}

No potential conflict of interest was reported by the author(s).

\section{Funding}

This research was funded through the University of Liège (ULg) and ARC grant for Concerted Research Actions, financed by the French Community of Belgium, Wallonia-Brussels Federation (CityRoof project: Analogous green roofs for urban ecosystem services (2020-2023)).

\section{References}

Akbarzadeh Bengar, H., Shahmansouri, A.A., Akkas Zangebari Sabet, N., Kabirifar, K., Tam, W.Y.V. (2020). Impact of elevated temperatures on the structural performance of recycled rubber concrete: experimental and mathematical modeling. Construction and Building Materials, 255, 119374.

Altamirano-Medina, H., Davies, M., Ridley, I., Mumovic, D., Oreszczyn, T. (2009). Guidelines to avoid mould growth in buildings. Advances in Building Energy Research, 3, 221-235.

Amiri Fard, F., Jafarpour, A., Nasiri, F. (2019). Comparative assessment of insulated concrete wall technologies and wood-frame walls in residential buildings: a multi-criteria analysis of hygrothermal performance, cost, and environmental footprints. Advances in Building Energy Research, 1-33.

Antretter, F. Sauer, F., Schopfer, T., Holm, A. (2011). Validation of a hygrothermal whole building simulation software, in: Proc. of Building Simulation 2011, 12th Conference of International Building Performance Simulation Association, Sydney, 1694-1701.

ASHRAE Standard 160. (2009). Criteria for moisture-control design analysis in buildings.

AzariJafari, H., Shekarchi, M., Berenjian, J., Ahmad, B. (2015). Enhancing workability retention of concrete containing natural zeolite by superplasticizers' combination. Special Publication, 302, 416-424.

Berardi, U., GhaffarianHoseini, A., GhaffarianHoseini, A. (2014). State-of-the-art analysis of the environmental benefits of green roofs. Applied Energy, 115, 411-428.

Berndtsson, J.C., Emilsson, T., Bengtsson, L. (2006). The influence of extensive vegetated roofs on runoff water quality. Science of the Total Environment. 48-63.

Bianchini, F., Hewage, K. (2012). How "green" are the green roofs? Lifecycle analysis of green roof materials. Building and Environment, 48, 57-65.

Budaiwi, I., Abdou, A. (2013). The impact of thermal conductivity change of moist fibrous insulation on energy performance of buildings under hot-humid conditions. Energy and Buildings, 60, 388-399.

Burch, D.M., Chi , J. (1997). MOIST -A PC program for predicting heat and moisture transfer in building envelopes, National Institute of Standards and Technology (NIST), Gaithersburg, USA, Special Publication 917.

CABR (2014). Thermal design code for civil building (GB 50176-201X). China Building Industry Press, Beijing.

Cascone, S., (2019), Green roof design: State of the art on technology and materials, Sustainability (Switzerland), 11(11), $1-27$.

Cascone, S., Catania, F., Gagliano, A., Sciuto, G. (2018). A comprehensive study on green roof performance for retrofitting existing buildings. Building and Environment, 136, 227-239.

Chenani, S.B., Lehvävirta, S., Häkkinen, T. (2015). Life cycle assessment of layers of green roofs. Journal of Cleaner Production, 90, 153-162. 
Coma, J., Pérez, G., Castell, A., Solé, C., Cabeza, L.F. (2014). Green roofs as passive system for energy savings in buildings during the cooling period: use of rubber crumbs as drainage layer. Energy Efficiency, 7, $841-849$.

Coma, J., Pérez, G., Solé, C., Castell, A., Cabeza, L.F. (2016). Thermal assessment of extensive green roofs as passive tool for energy savings in buildings. Renewable Energy, 85(11), 1106-1115.

Courard, L., Rondeux, M., Zhao, Z., Michel, F. (2020). Use of recycled fine aggregates from C\&DW for unbound road sub-base. Materials, 1-26.

Crafford, P.L., Wessels, C.B., Blumentritt, M. (2018). Sustainability and wood constructions: a review of green building rating systems and life-cycle assessment methods from a South African and developing world perspective. Advances in Building Energy Research, 1-20.

Dassault Systemes. 2009. Abaqus/CAE User's Manual. Hibbitt, Karlsson \& Sorensen, Inc.

Delgado, J.M.P.Q., Barreira, E., Ramos, N.M.M., de Freitas, V.P. (2013). Hygrothermal Numerical Simulation Tools Applied to Building Physics, Springer-Verlag.

Deshmukh, G.; Birwal, P.; Datir, R.; Patel, S. (2017). Thermal insulation materials: A tool for energy conservation. Journal of Food Processing \& Technology, 8, 1-4.

Dvoraka, B., Volder, A. (2013). Rooftop temperature reduction from unirrigated modular green roofs in south-central Texas. Urban Forestry \& Urban Greening, 12, 28-35.

Ebadati, M., Ehyaei, M.A. (2018). Reduction of energy consumption in residential buildings with green roofs in three different climates of Iran. Advances in Building Energy Research, 14(1), 66-93.

Eksi, M., Rowe, D.B., Wichman, I.S., Andresen, J.A. (2017). Effect of substrate depth, vegetation type, and season on green roof thermal properties. Energy and Buildings, 145, 174-187.

Fan, X., Liu, W., Wargocki, P. (2019). Physiological and psychological reactions of sub-tropically acclimatized subjects exposed to different indoor temperatures at a relative humidity of 70\%. Indoor Air, 29 (2), 215-230.

Ferrante, A., Boiardi, L., Fotopoulou, A. (2015). On the viability of nearly zero energy buildings in the Mediterranean urban contexts, Advances in Building Energy Research, 9(2), 190-223.

Fraunhofer IBP (Fraunhofer Institute for Building Physics). (2015). WUFI Pro. [Computer software]. Stuttgart, Germany: Fraunhofer IBP.

Jafari, K., Toufigh, V. (2017). Experimental and analytical evaluation of rubberized polymer concrete. Construction and Building Materials, 155, 495-510.

Jarrah, M., Khezrzadeh, H., Mofid, M., Jafari, K. (2019). Experimental and numerical evaluation of pistonmetallic damper (PMD). Journal of Constructional Steel Research, 54, 99-109.

Jim, C.Y. (2014) Air-conditioning energy consumption due to green roofs with different building thermal insulation. Applied Energy, 128, 49-59.

Jim, C.Y., Tsang, S.W. (2011). Modeling the heat diffusion process in the abiotic layers of green roofs. Energy and Buildings, 43(6), 1341-1350.

Jin, L., Zhang, Y., Zhang, Z. (2017). Human responses to high humidity in elevated temperatures for people in hot-humid climates. Building and Environment, 114, 257-266.

Karamanis, D., Kyritsi, E., Krimpalis, S., Vardoulakis, E., Gorgolis, G., Kapsalis, V., Mihalakakou, G., Ökte, N. (2013. Cooling roofs through low temperature solar-heat transformations in hydrophilic porous materials. Advances in Building Energy Research, 7(2), 235-243.

Karatzas, K., Katsifarakis, N. (2018). Modelling of household electricity consumption with the aid of computational intelligence methods. Advances in Building Energy Research, 12 (1), 84-96.

Kapsalis, V.C., Vardoulakis, E., Karamanis D. (2014). Simulation of the cooling effect of the roof added photovoltaics. Advances in Building Energy Research, 8(1), 41-54.

Karamanis, D., Kyritsi, E., Krimpalis, S., Vardoulakis, E., Gorgolis, G., Kapsalis, V., Mihalakakou, G., Ökte, N. (2013). Cooling roofs through low temperature solar-heat transformations in hydrophilic porous materials, Advances in Building Energy Research, 7(2), 235-243.

Kazemi, M. Hajforoush, M., Khakpour Talebi, P., Daneshfar, M., Shokrgozar, A., Jahandari, S., Saberian, M., Li, J. (2020). In-situ strength estimation of polypropylene fibre reinforced recycled aggregate concrete using Schmidt rebound hammer and point load test. Journal of Sustainable Cement-Based Materials, 9, 1-18.

Kazemi, M., Kafi, M.A., Hajforoush, M., Kheyroddin, A. (2020). Cyclic behavior of steel ring filled with compressive plastic or concrete, installed in concentric bracing system, Asian Journal of Civil Engineering, 21, $29-39$.

Kazemi, M., Li, J., Harehdasht, S.L., Yousefieh, N., Jahandari, S., Saberian, M. (2019). Non-linear behaviour of concrete beams reinforced with GFRP and CFRP bars grouted in sleeves. Structures, 23, 87-102.

Kazemi, M., Madandoust, R., de Brito, J. (2019). Compressive strength assessment of recycled aggregate concrete using Schmidt rebound hammer and core testing. Construction and Building Materials, 224, 630-638.

Künzel, H.M. (1994). Verfahren Zur ein- und zweidimensionalen Berechnung des- gekoppelten Wärme- und Feuchtetransports in Bauteilen mit Einfachen Ken- nwerten, Universität Stuttgart.

Lei, K.-T., Tang, J.-S., Chen, P.-H. (2019). Numerical simulation and experiments with green roofs for increasing indoor thermal comfort. Journal of the Chinese Institute of Engineers, 42(4), 346-356. 
Li, Y., Zhu, Q. (2003). Simultaneous heat and moisture transfer with moisture sorption, condensation and capillary liquid diffusion in porous textiles, Text. Res. J., 73(6), 515-524 (2003).

Ling, H., Chen, C., Qin, H., Wei, S., Lin, J., Li, N., Zhang, M., Yu, N., Li Y. (2016). Indicators evaluating thermal inertia performance of envelops with phase change material. Energy and Buildings, 122, 175-184.

Madandoust, R., Kazemi, M. (2017). Numerical analysis of break-off test method on concrete. Construction and Building Materials, 151, 487-493.

Madandoust R., Kazemi M., Khkapour Talebi P., de Brito J. (2019). Effect of the curing type on the mechanical properties of lightweight concrete with polypropylene and steel fibres. Construction and Building Materials, 223, $1038-1052$.

Mickovski, S.B., Buss, K., McKenzie, B.M., Sökmener, B. (2013). Laboratory study on the potential use of recycled inert construction waste material in the substrate mix for extensive green roofs. Ecological Engineering, 61, $706-714$.

Mohammadi, M., Kafi, M.A., Kheyroddin, A., Ronagh, H.R. (2019). Experimental and numerical investigation of an innovative buckling-restrained fuse under cyclic loading. 22, 186-199.

Mohammed, B.S., Hossain, K.M.A., Swee, J.T.E., Wong, G., Abdullahi, M. (2012). Properties of crumb rubber hollow concrete block, Journal of Cleaner Production, 23, 57-67.

Navarro, L., Garcia, A.D., Solé, C., Castell, A., Cabeza, L.F. (2012). Thermal loads inside buildings with phase change materials: experimental results. Energy Procedia, 20, 342-349.

Nematzadeh, M., Shahmansouri, A.A., Fakoor, M. (2020). Post-fire compressive strength of recycled PET aggregate concrete reinforced with steel fibers: optimization and prediction via RSM and GEP. Construction and Building Materials, 252, 119057.

Ngan, G. (2004). Green roof policies: Tools for encouraging sustainable design. Landscape Architecture Canada Foundation, 2-49.

Oberndorfer, E., Lundholm, J., Bass, B., Coffman, R.R., Doshi, H., Dunnett, N., Gaffin, S., Kohler, M., Liu, K.K.Y., Rowe, B. (2007) Green roofs as urban ecosystems: ecological structures, functions, and services. BioScience, 57(10), 823-833.

Palla, A., Gnecco, I., Lanza, L.G. (2009). Unsaturated 2D modelling of subsurface water flow in the coarse-grained porous matrix of a green roof. Journal of Hydrology, 379, 193-204.

Papafotiou, M., Pergialioti, N., Tassoula, L., Massas, I., Kargas, G. (2013). Growth of native aromatic xerophytes in an extensive Mediterranean green roof, as affected by substrate type and depth, and irrigation frequency. HortScience, 48, 1327-1333.

Parizotto, S., Lamberts, R. (2011). Investigation of green roof thermal performance in temperate climate: A case study of an experimental building in Florianópolis city, Southern Brazil, Energy and Buildings, 43, 1712-1722.

Pérez, G., Coma, J., Solé, C., Castell, A., Cabeza, L.F. (2012). Green roofs as passive system for energy savings when using rubber crumbs as drainage layer. Energy Procedia, 30, 452-460.

Pérez, G., Vila, A., Rincón, L., Solé, C., Cabeza, L.F. (2012). Use of rubber crumbs as drainage layer in green roofs as potential energy improvement material. Applied Energy, 97, 347-354.

Pfretzschner, J., Rodriguez, R.M. (1999). Acoustic properties of rubber crumbs. Polymer Testing, 18(2), 81-92.

Raji, B., Tenpierik, M.J., van den Dobbelteen, A. (2015). The impact of greening systems on building energy performance: a literature review. Renewable \& Sustainable Energy Reviews, 45, 610-623.

Ramin, H., Hanafizadeh, P., Ehterami, T., AkhavanBehabadi. M.A. (2019). Life cycle-based multi-objective optimization of wall structures in climate of Tehran. Advances in Building Energy Research, 13(1), 18-31.

Saberian, M., Li, J., Cameron, D. (2019a). Effect of crushed glass on behavior of crushed recycled pavement materials together with crumb rubber for making a clean green base and subbase. Journal of Materials in Civil Engineering, 31 (7), 04019108.

Saberian, S., Li, J., Setunge, S. (2019). Evaluation of permanent deformation of a new pavement base and subbase containing unbound granular materials, crumb rubber and crushed glass, Journal of Cleaner Production, 230, 38-45.

Sadeghian, F., Haddad, A., Jahandari, S., Rasekh, H., Ozbakkaloglu, T. (2020). Effects of electrokinetic phenomena on the load-bearing capacity of different steel and concrete piles: A small-scale experimental study. Canadian Geotechnical Journal, 1-16.

Sailor, D.J., Hagos, M. (2011). An updated and expanded set of thermal property data for green roof growing media. Energy and buildings, 43, 2298-2303.

Schafaczek, B., Zirkelbach, D. (2013). Ermittlung von Materialeigenschaften undeffektiven Übergangsparametern von Dachbegrünungen zur zuverlässigen Simulation der hygrothermischen Verhältnisse in und unter Gründächern beibeliebigen Nutzungen und unterschiedlichen Standorten, Forschungsinitiative Zukunft Bau, F 2863, Band.

Schulte-Wrede, M., Merk, M., Gamper, A., Winter, S., Wolf, A. (2012). Hygrothermal behaviour of a large scale wooden flat roof structure in Central Europe. WCTE 2012, Auckland, 55-62.

Soleimani, S.S., Jahandari, S., Aberoumand, S., Rahmani, A., Shokrgozar, A. (2020). Cu/Oil nanofluids flow over a semiinfinite plate accounting an experimental model. Heat Transfer Asian Research, 49(3), 1338-1354.

Stovin, V., Poë, S., De-Ville, S., Berretta, C. (2015). The influence of substrate andvegetation configuration on green roof hydrological performance. Ecological Engineering, 85, 159-172. 
Tabares-Velasco, P.C., Zhao, M., Peterson, N., Srebric, J., Berghage, R. (2012). Validation of predictive heat and mass transfer green roof model with extensive green roof field data. Ecological Engineering, 47, 165-173.

Teemusk, A., Mander, U.1. (2009). Green roof potential to reduce temperature fluctuations of a roof membrane: A case study from Estonia. Building and Environment, 44, 643- 650.

Theodosiou, T. (2011) Green roofs in buildings: thermal and environmental behavior. Advances in Building Energy Research, 3(1), 271-288.

Ting, M.-H. (2011). Numerical simulation of the general insulation material in the application of increasing indoor thermal comfort. Master Thesis, Department of Civil Engineering, National Taiwan University. (In Chinese).

Toghroli, A., Mehrabi, P., Shariati, M., Trung, N.T., Jahandari, S., Rasekh, H., (2020). Evaluating the use of recycled concrete aggregate and pozzolanic additives in fiber-reinforced pervious concrete with industrial and recycled fibers. Construction and Building Materials, 252, 1-22.

Tommasi, P., Verrucci, L., Rotonda, T. (2015). Mechanical properties of a weak pyroclastic rock and their relationship with microstructure. Canadian Geotechnical Journal, 52(2), 211-223.

Tsutsumi, H., Tanabe, S., Harigaya, J., Iguchi, Y., Nakamura, G. (2007). Effect of humidity on human comfort and productivity after step changes from warm and humid environment. Building and Environment, 42(12), 4034-4042.

Uhl, M., Schiedt, L. (2008). Green roof storm water retention -monitoring results. In: 11th International Conference on Urban Drainage, Edinburgh, Scotland, UK, 31/ 8-5/9.

Vertal' M., Zozulák, M., Vašková, A., Korjenic, A. (2018). Hygrothermal initial condition for simulation process of green building construction. Energy and Buildings, 167, 166-176.

Vesuviano, G., Stovin, V. (2013). A generic hydrological model for a green roof drainage layer. Water Science \& Technology, 68(4), $769-775$.

Vijayaraghavan, K.U., Joshi, U.M., Balasubramanian, R. (2012). A field study to evaluate runoff quality from green roofs. Water Research, 46, 1337-1345.

Vijayaraghavan, K. (2016). Green roofs: A critical review on the role of components, benefits, limitations and trends, Renewable and Sustainable Energy Reviews, 57, 740-752.

Vila, A., Pérez, G., Solé, C., Fernández, A.I., Cabeza, L.F. (2012). Use of rubber crumbs as drainage layer in experimental green roofs. Building and Environment, 48, 101-106.

Wanielista, M., Kelly, M., Hardin, M. (2008). A comparative analysis of green roof designs including depth of media, drainage layer materials, and pollution control media. Florida Department of Environmental Protection: Tallahassee, FL, USA.

Yu, C., Hien, W.N. (2009). Thermal impact of strategic landscaping in cities: a review. Advances in Building Energy Research, 3(1), 237-260.

Zhao, Z., Courard, L., Groslambert, S., Jehin, T., Léonard, A., Jianzhuang, X. (2020). Use of recycled concrete aggregates from precast block for the production of new building blocks: An industrial scale study. Resources, Conservation and Recycling, 157.

Zirkelbach, D. (2017). Green roofs- hygrothermal simulation of moisture and energy performance, Proceedings of the $1^{\text {st }}$ International Conference on Construction Materials for Sustainable Future, Zadar, Croatia, 19 - 21 April, pp. 810 815.

Zirkelbach, D., Mehra, S.-R., Sedlbauer, K.-P., Künzel, H.-M., Stöckl, B. (2017). A hygrothermal green roof model to simulate moisture and energy performance of build- ing components. Energy and Buildings, 145, 79-91. 